بالة المشرثة

YrV

المرأة ودورها في نشأة الدولة العثمانية

"Devlet Ana" لطارق بوغرايتا و" Ossmancık" لكمال طاهر أنموذجًا

د.أحمد مراد محمود الدسوقي (*)

همدهمة

المرأة نصف المجتمع، وهي المسؤولة عن تنشئة النصف الآخر. إن صلحت صلح المجتمع بنياناً وأساساً. وحتى في أحلك الفترات وأشدها قسوة والتي تتوارى فيها أدوار النساء خلف الرجال الذين يظهرون في المقدمة يكنَّ هن من يمسكن بزمام المجتمع ويدعمن الرجال في مواقفهم، وأحياناً كثيرة يكن أكبر دافع للرجال نحو الدفاع عن أوطانهم، وزود المخحاطر عنه.

وقد لعبت المرأة في فترة إنشاء الدولة العثمانية دوراً بالغ الأهمية؛ إذ وقفت جنباً إلى جنب مع الرجل تدعمه وتشد من أزره حتى استطاعا سوياً في النهاية أن يؤسسا دولة عاشت لقرون. ويظهر هذا الدور في الروايات التركية التي تتناول بدايات أو فترة تأسيس الدولة العثمانية، بل وتؤكد الرواية التركية على هذا الدور ومن تلك الروايات رواية "Osmanc1k" (عثمانجيك- وتعني عثمان الصغير) للأديب "طارق بوغرا"' والتي صدرت طبعتها الأولى عام

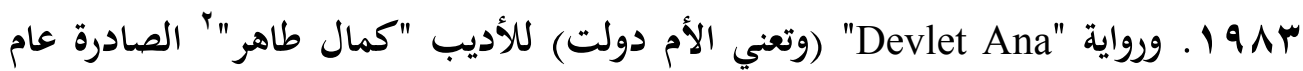
" - مدرس الأدب التركي الحديث بقسم اللغات الثرقية الإسلامية ، شعبة اللغة التركية - كلية الألسن - جامعة عين شمس. 
197V ا ـ وكان هذا هو السبب الرئيس لاختيار الروايتين المذكورتين لهذه الدراسة. حيث انحصر دور المرأة في رواية الحرب والرواية التاريخية بصفة عامة في دور الأم أوالزوجة

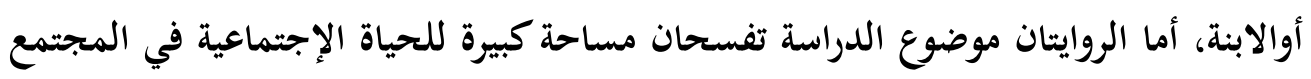
التركي آنذاك؛ وهما من أشهر الروايات التركية التي تناولت فترة تأسيس الدولة العثمانية، ولم

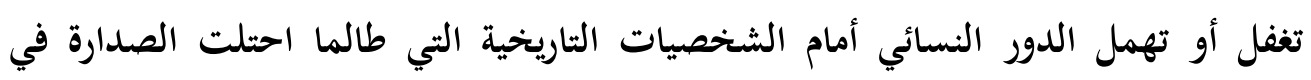
الأعمال التاريخية بل والأدبية أيضاً.

ترجع أهمية الموضوع إذاً وسبب اختياره للدراسة هو إبراز دور المرأة في بناء المجتمع

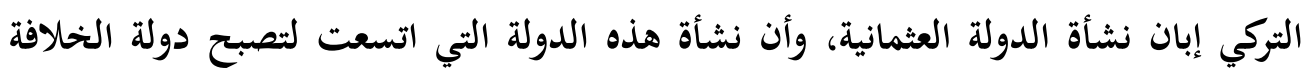
الإسلامية لما يزيد عن أربعة قرون إنما كانت بإيمان المجتمع بأهمية المرأة ودورها الرائد فيه

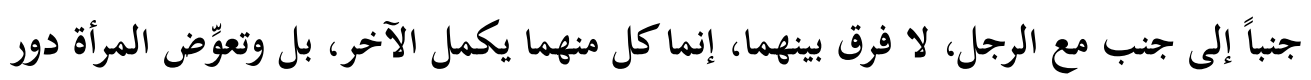

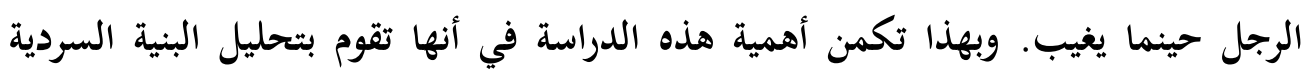

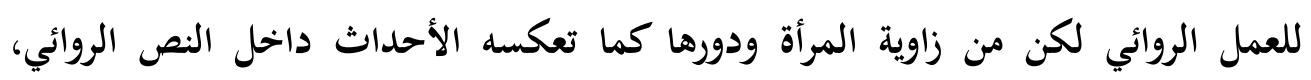
وبالطبع الدلالة الفكرية لهذا الدور وانعكاسه وعلاقته بالواقع.

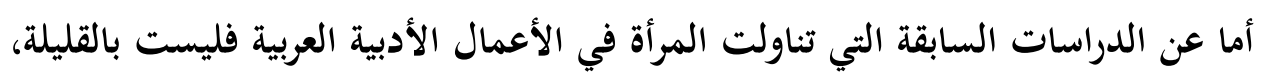

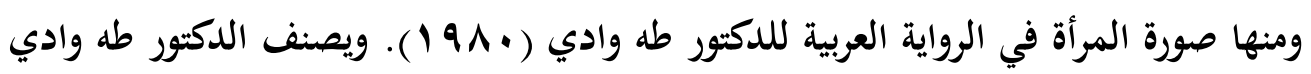
في دراسته هذه صورة المرأة وفقاً للتيارين الأدبيين الرومانسي والواقعي. وهي جد دراسة رائدة في هذا المجال، وسارت على دربها العديد من الدراسات حتى يومنا هذا مثل صورة

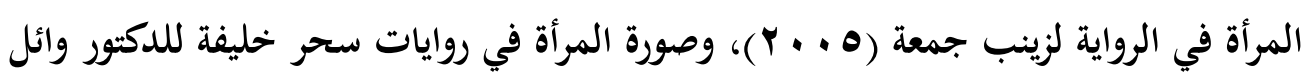
فالح الصمادي (• ( • ( ))، وصورة المرأة في روايات نجيب محفوط الواقعية، لسناء الجمالي

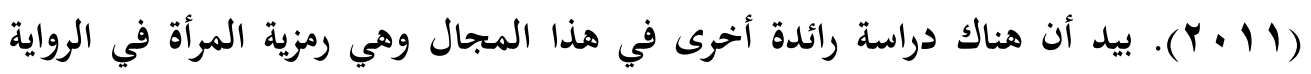

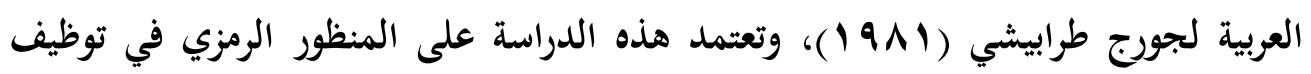
المرأة داخل الرواية العربية. 
رسالة المشرة

\section{$\overline{r r q}$}

أما في الدراسات التركية في تركيا التي تناولت مثل هذا الموضوع فإنها نادرة إلى حد كبير، وذات اتجاه عام، حيث تتناول بالتحليل البطلات في أدب مرحلة ما أو في أعمال أديب محدد، وأول هذه الدراسات كانت بعنوان "البطلات في الرواية التركية لعصر التنظمات "“، وهي رسالة دكتوراه؛. وسارت على دربها العديد والعديد من الدراسات اللاحقة لها مثل "المرأة في قصص مصطفى قوتلو"ه، وقد قسمت الدراسة نماذج المرأة الواردة في المجموعات القصصية وفقاً لدورها داخل العمل الأدبي، ثم وفقاً لنموذج الشخصية ما بين أهل القرية وأهل المدينة. وهناك دراسة أخرى باسم "البطلات في روايات كمال طاهر" ". وهذه الدراسة الأخيرة وإن كانت أكثر تلك الدراسات قرباً من موضوع الدراسة، إلا أن إندان الباحث لم يتسن له الإفادة منها نظراً لاتسامها بالسطحية في التناول العام للبناء الدرامي للشخصية، حيث قامت الدراسة بتناول كل أعمال الأديب الروائية وتبلغ تسع عشرة رواية، مع تقسيم الشخصيات لرئيسي وفرعي، مما جعل الدراسة تتسم بالسطحية في نهاية المطاف. ومع ذلك آثر الباحث ذكرها في الدرسات السابقة وفقاً لأدبيات البحث العلمي. أما هذه الدراسة فتتشكل من مقدمة حول أهمية البحث وسبب اختياره للدراسة والدراسات السابقة ومنهجية الدراسة، ثم تمهيد عن البناء الفني للشخصية الروائية، وهو يمثل مدخلاً نظرياً للبنية الفنية للشخصية داخل النص الروائي، يليه ثلاثة مباحث رئيسة كالثالي: المبحث الأول: "دولت خحاتون" (Devlet Hatun) أو "الأم دولت" (Devlet Ana) في رواية "Devlet Ana" لكمال طاهر. المبحث الثاني: "جوكتشه باجي" (Gökçebac1) في رواية عثمانجيك (Osmanc1k) لطارق بوغرا. المبحث الثالث: الصورة الرمزية للمرأة في الروايتين، ثم الخاتمة وتدور حول أهم ما توصلت إليه الدراسة من نتائج وتوصيات، وأخيراً ثبت للمصادر والمراجع المعتمد عليها الباحث في هذه الدراسة، وهي تنقسم إلى: أولاً المراجع: الروايتان موضعا الدراسة.

ثانياً المصادر: الدراسات النقدية والأدبية التي تناولت الرواية بوجه عام والرواية التركية 
ويعتمد الباحث في دراسته هذه على المنهج النقدي التحليلي مع الإفادة من الدراسات النقدية في التحليل الفني الروائي من خلال تحليل البنية الفنية للشخصية الأدبية وتطورها داخل نسيج العملين الروائيين موضوعي الدراسة.

\section{تمهيد: البنـاء الفنسي لاشخمية الروائية}

الثخصية عنصر رئيس ومكون أصيل في الأعمال الأدبية التي تعتمد على السرد سواء

أكانت قصة أو رواية أو مسرحية. فلا يمكن تخيل عملاً أدبياً سردياً بلا شخصية أو الو شخصيات.

للشخصية دور بالغ الأهمية في النص السردي، فهي المحور الذي تدور حوله الأحداث، وبتعبير آخر هي تلك الأدوات التي تحرك الأحداث، وتدفع بها إلى الأمام، وتشكلها. لذا لا يمكن أن يخلو نص سردي سواء أكان قصة أو مسرح أو رواية من الثخصيات.V ليديد أن الشخصية لا تقتصر على البشر فقط، وإنما تتعداه لتشمل كل ما يؤدي فعلاً أو يمارس تأثيراً، فالمكان يمكن أن يكون شخصية أو بطلاً في إحدى الأعمال الأدبية، وكذلك الطير والحيوان والشجر. ^ لكن رغم ذلك فإن الإنسان هو محور العمل الأدبي السردي سواء كان قصة أو رواية أو مسرحية؛ حيث إن موضوع العمل الأدبي أياً ماكانت هوية أبطاله إنما هو

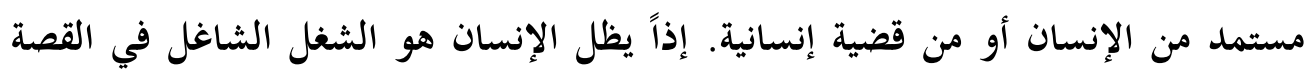

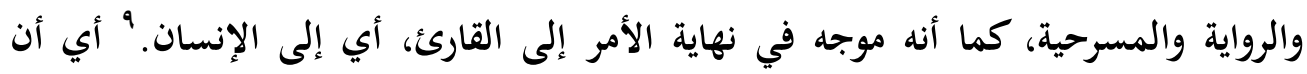
الشخصيات في النص الأدبي حتى وإن كانوا غير بشر، إلا أنهم يعبرون عن قضية مستوحاة من الإنسان. فهم -أي الشخصيات- في تلك الحالة تصير مجرد رمز تعبر في حقيقة عن عالم الإنسان وتستمد منه كل دلالاته.

"ومن البديهي أنه ما من حدث يقع بالطريقة المعينة التي وقع بها وإلا كان نتيجة لوجود

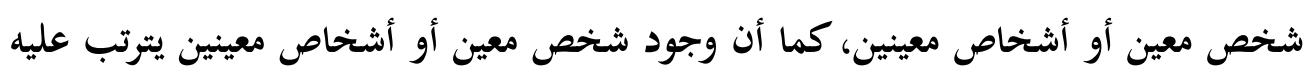
وقوع الحدث بطريقة معينة. وبذلك يكون من الخطأ الفصل أو التفرقة بين الشخصية وبين الحدث؛ لأن الحدث هو الشخصية وهي تعمل أو هو الفاعل وهو يفعل. فلو أن الكاتب 
رسالة المشرة

\section{$\overline{Y \xi 1}$}

اقتصر على تصوير الفعل دون الفاعل لكانت قصته أقرب إلى الخبر المجرد منها إلى القصة،

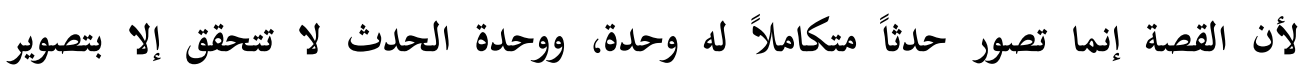

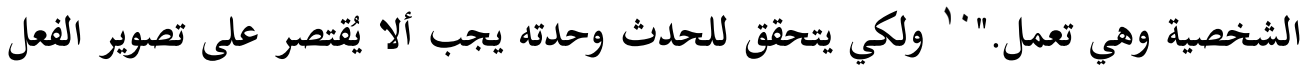

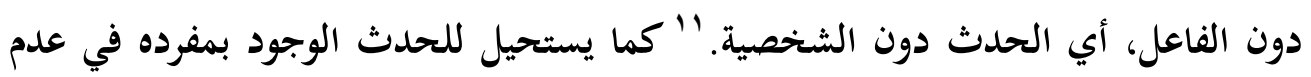
وجود الشخصية؛ لأن الشخصية هي التي تجعل للحدث وجود، وتقوم وتنهض به، وتطوره، أما دونها فلا يكون سوى حيز لغوي أجوف.

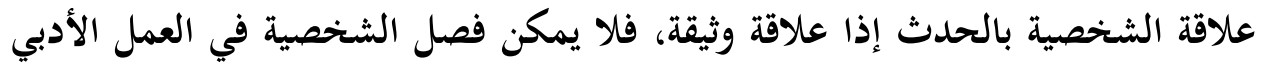

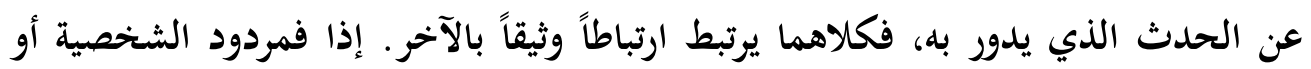
الدور الملقى على عاتقها سيكون له علاقة كذلك ببناء هذه الشخصية.

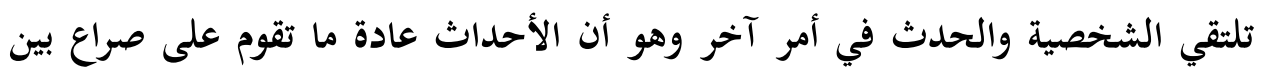
قوتين أو عالمين، العالم الأول يمثله البطل الرئيس داخل القصة، والعالم الآخر يمثله العالم

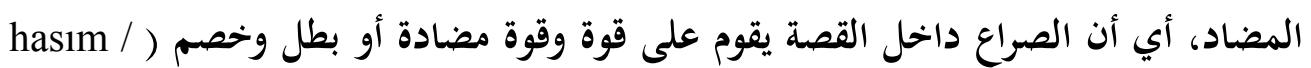

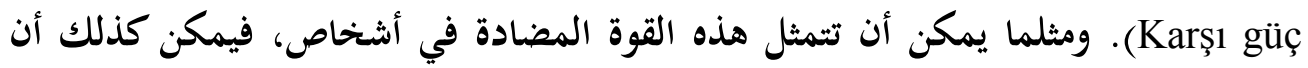

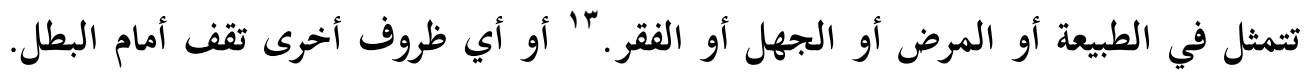

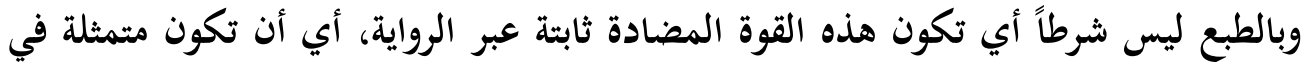

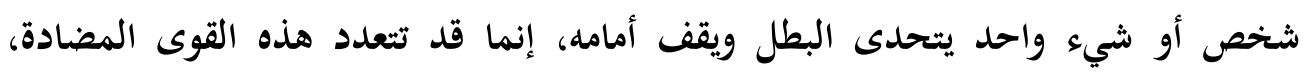
وتختلف من مرحلة لأخرى من مراحل الرواية. وإن كانت هذه القوة المضادة تشكل الصراع

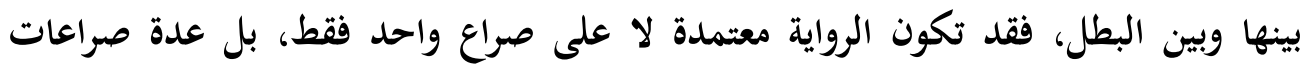

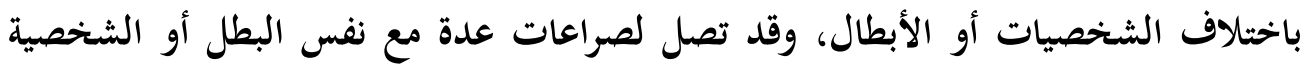

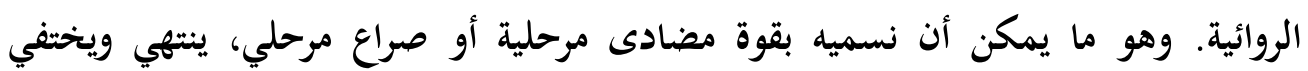
بانتهاء دوره والمراد منه داخل الرواية. وسيعرض الباحث الأمثلة على هذه النوعية من الصراع أو القوة المضادة في المبحث التالي. 
ثمة أمر آخر متعلق بتقديم السادر للشخصيات، ألا وهو طريقة تقديم هذه الشخصيات داخل الأعمال الأدبية السردية، ويعتد هذا الأمر على طريقتين، أولهما الطريقة التقليدية وهي التعريف المباشر بالشخصية من خلال السرد "Blok Tanitma"، حيث يتم إيقاف الحدث داخل العمل الأدبي ويقوم الكاتب بسرد صفات البطل، كأن يذكر الكاتب أن هذا الشخص أو ذاك شاب ذكي ومتزوج ويعمل في إحدى الثركات، أو أن تقوم الشخصية بوصف نفسها بنفسها. أما الطريقة الثانية فهي التعريف غير المباشر بالشخصية "Dinamik Tanıtma" وهي تستمر طوال العمل الأدبي، حيث يستبط القارئ صفات البطل من خلال المواقف والأحداث، مثل تصرفات البطل في موقف ما، أو موقفه وردود أفعاله من أراء وأفكار معينة وغير ذلك. أي وصف الآخرين لها. ' والروائيون غالباً ما يقومون بالمزج بين الطريقتين معاً. أما من حيث البناء النفسي للشخصيات داخل العمل الأدبي فهي إما أن تكون شخصيات بسيطة (düz/yalınkat kahramanlar) أو شخصيات معقدة أو عميقة ( / yuvarlak boyutlu kahramanlar الأعمال الأدبية عامة، وهي الشخصيات التي تظهر أمام القارئ طوال الأحداث بصفات محددة، دون أن يطرأ تغير على هذه الصفات طوال العمل الأدبي. وهذه الشخصيات ببنائها البسيط هذا تظل في عقل القارئ، ويمكنه تذكرها بكل سهولة لأنها تمثل نموذجاً لشخصية ما، كنموذج المزارع أو نموذج الطالب أو نموذج العامل أو نموذج الموظف. أما الشخصيات المعقدة فهي على النقيض تماماً من الشخصيات البسيطة بعمقها وبوضعها النفسي. فهي شخصيات تتغير باستمرار على مدار الأحداث داخل العمل الأدبي، ولا يمكن توقع تصرفاتها

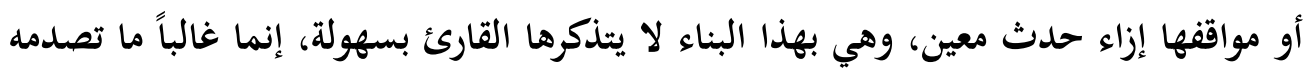
أو تثير دهشته داخل النص، بل ويمكن أن تخدعه. 14 وأخيراً فإن الشخصية في الرواية خصوصاً تحمل أهمية بالغة نظراً لبناء الرواية لاسيما

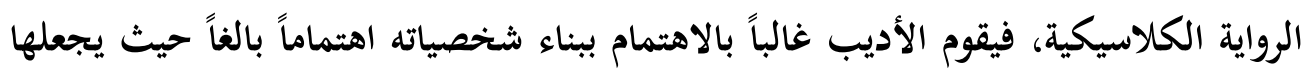
غالباً تقوم بحمل رسائله التي أراد إيصالها للقارئ في الأساس. فالشخصية هي العنصر الفني 
رسالة المشرة

\section{$\overline{Y \varepsilon Y}$}

الرئيس الذي تتبلور حوله الأحداث، وتتطور في حيزها وإطارها، وهي عنصر لا تستقيم الرواية بلدونه، ولا يمكن لبنائها أن يتم بمنأى عنه.

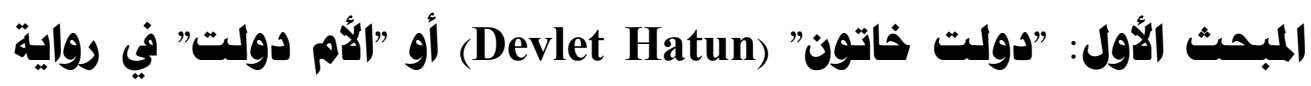

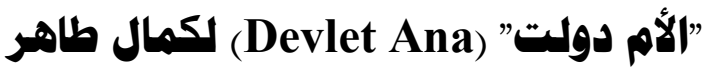

رواية "الأم دولت" (Devlet Ana) رواية تاريخية تتناول الفترة الأولى لتأسيس الدولة

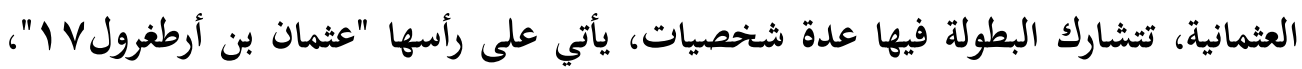
و"الأم دولت" أو "دولت خاتون".

يبدأ الحديث في مقتبل الرواية عن البطلة ولكن باسم آخر وهو "باجي بي" (Bacibey) دون أن تظهر هي في الأحداث، أي يتم الإشارة إليها عبر أبطال آخرين، وكأن الكاتب يقدم لشخصيته، ويمهد للقارئ هذه الشخصية التي ستظهر فيما بعد، وكأنها شخصية يهابها

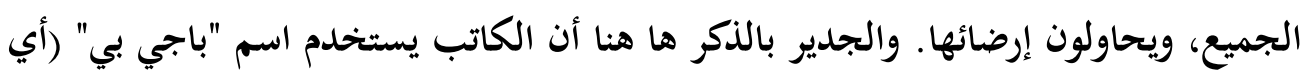
السيدة الزعيمة) في وضع يعبر فيه عن قوة شخصيتها: "إن والدة صهري تصر على أن تكون زوجة ابنها تركية... وتأوه. إن والدة صهري عنيدة. وعناد "باجي بي" ذاع صيته من قونية إلى

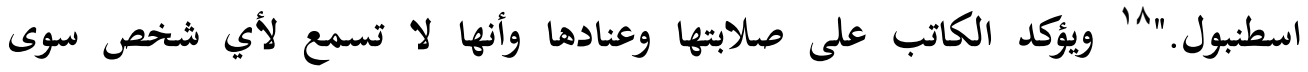
لآرطغرول" و ويأتي كل ذلك على لسان أحد شخصيات الرواية وهو "مافرو" (Mavro) كالتالي: "حتى النساء عند آرطغرول بك مقاتلات. ويطلقون عليهن "مقاتلات الأناضول" وزعيمتهن هي "باجي بي" والدة صهري "دميرجان". والتقليد عند هؤلاء النسوة هو نشر الدين مثلهم مثل الغزاة والمحاربين. أفهمت الآن لماذا لم توافق "باجي بي" حتى الآن مطلب

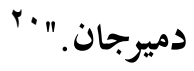

ويظل الكاتب يقدم بين الحين والآخر معلومات يشوق بها القارئ عن شخصية "باجي بي" أو "الأم دولت". ثم تظهر شخصية البطلة "دولت خاتون" (تعني السيدة دولت) أو "الأم دولت" في الرواية على أنها شخصية فذة، ليست كأي امرأة، فهي امرأة قائدة، مقاتلة، صلبة، طويلة القامة، مع ذكر سبب تسميتها بـباجي بي" ولكن هذه المرة من خلال التقديم المباشر 
للشخصية، أي أن الكاتب يوقف الأحداث ويخرج منها ليتحدث عن البطلة: "إن دولت خاتون والتي صاروا ينادونها "باجي بي" بمجرد ما أن تم اختيارها زعيمة لنساء الأناضول،

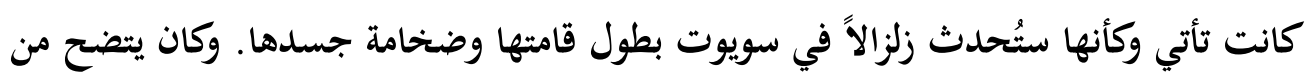
نضارتها قدر جمالها الفائق وذلك من عينيها الواسعتين السوداوين ومن أنفها الأقفية وخديها الممتلئين اللذين لا يبدو عليهما أي خشونة. كانت لا تقل عن المقاتلين في رمي السهام والرماح والقتال بالسيف والفروسية ولا تخذل أحداً في وقت المحن بشجاعتها. ومنذ وفاة زوجها "رستم بيلفان" في حملة على أراضي إيناجول وإلى الآن إلا وقد ازدادت صلابة، ولم

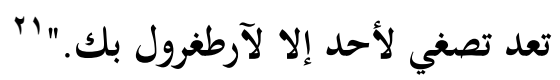

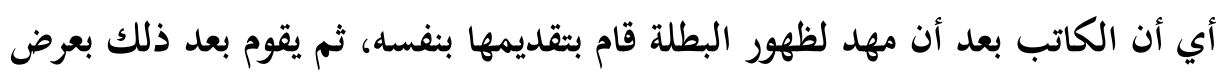
كل سماتها وصفاتها عبر الأحداث، ولا يتدخل ثانية من أجل إضاءة شخصيتها، فهي القادرة على ذلك في نظره. وحينما يتدخل من خلال السرد والتقديم المباشر ثانية يكون ذلك

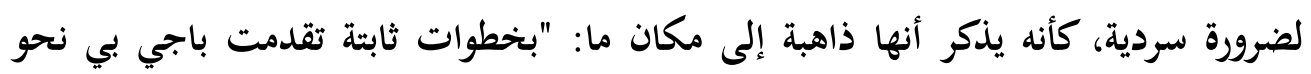

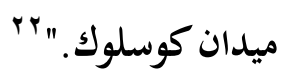

يتضح من هذه التقنية في تقديم الشخصية أن الكاتب على إيمان كامل بأنه بعد التقديم المباشر منه لهذه الشخصية فإنها فيما بعد هي من ستفرض نفسها من خحلال دورها وشخصيتها الفذة عبر أحداث الرواية فلا يعتمد على التقديم المباشر للشخصية اعتماداً

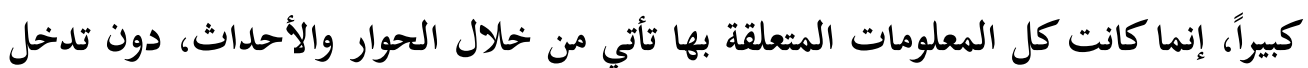
مباشراً من السارد. فعلى سبيل المثال تظهر أما القارئ في أكثر من مشهد وهي تحمل السوط بيدها، وتارة أخرى تظهر والسيف في إحدى يديها والقوس في اليد الأخرى للتعبير

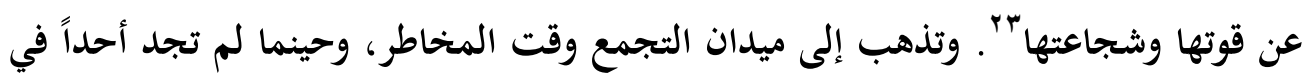
الميدان تقوم بقرع طبل الحرب إيذاناً منها بأن ثمة أمر هام، وبالفعل يأتي الجميع ملبياً النداء الذي أعلنته. وعند اتخاذ قرار الحرب تجلس في مجلس الحرب تحت قيادة لآرطفرول بك،

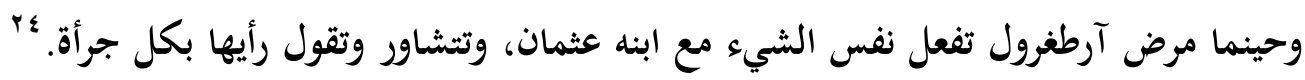


رسالة المشرة

\section{$\overline{r \varepsilon}$}

وتصطف وراءها مجموعة النساء المقاتلات بمجرد أمر واحد تصدره لهن. هب ويؤكد الكاتب

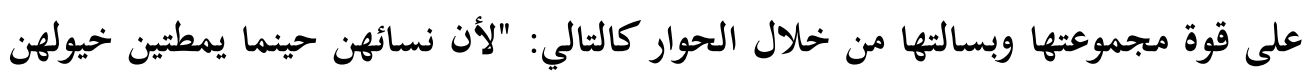

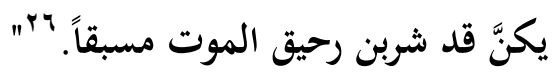

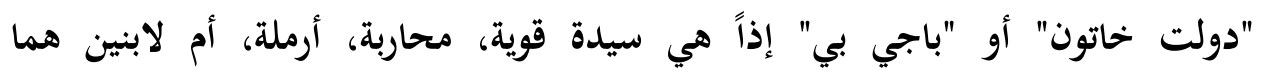

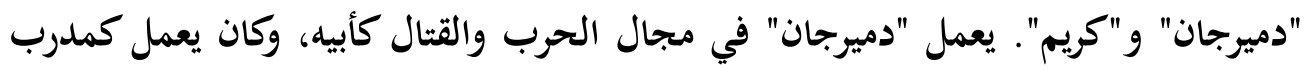

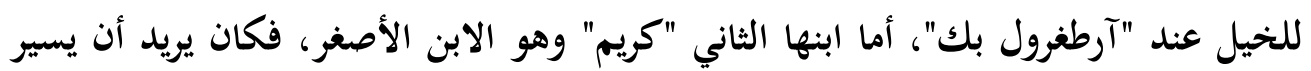

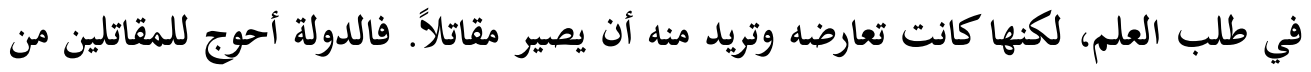

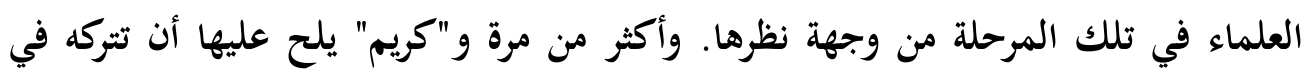

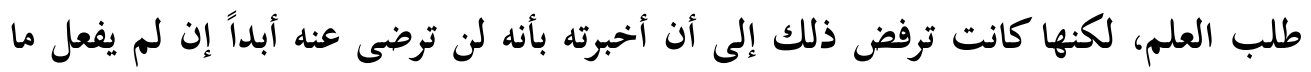
تريده منه، وأن لأمه حق عليه.

يعود الكاتب لاسم "باجي بي" ثانية بعد مقتل ابنها الكبير للدلالة على أنها لم تتأثر التأثر

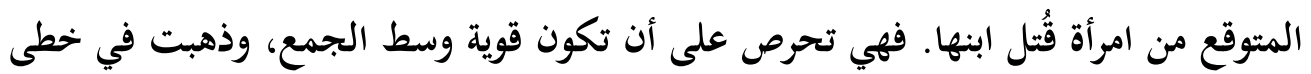

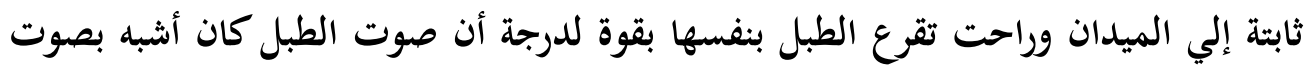

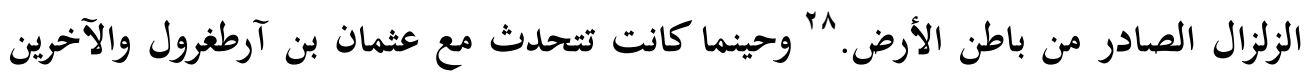

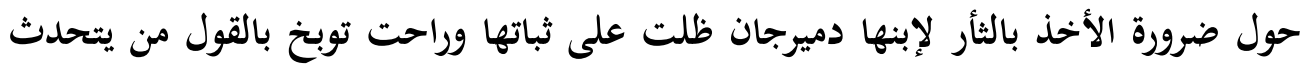

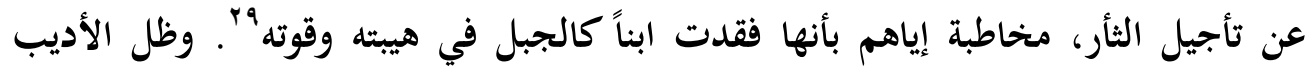

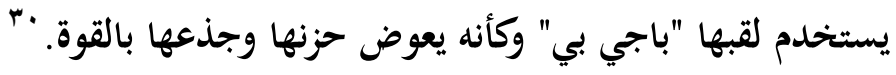

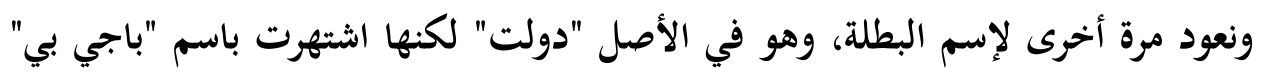
(ويعني سيدة النساء أو قائدتهن) وذلك عقب اختيارها زعيمة لنساء الأناضول المحاربات،

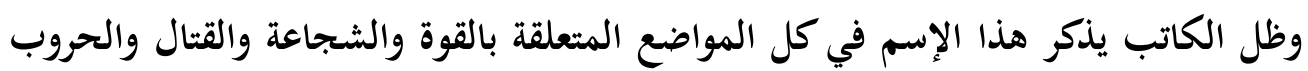

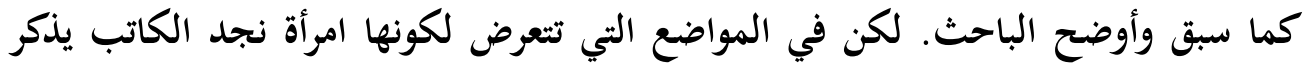

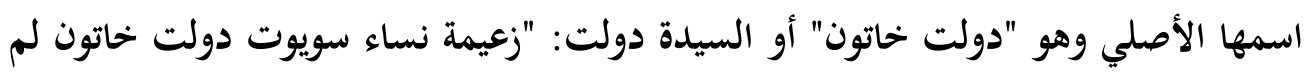

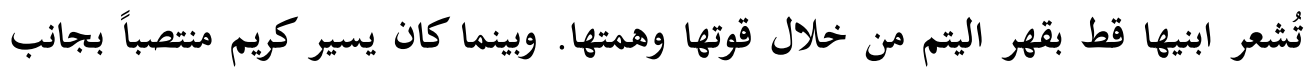


العربة التي تجرها الثيران، راح يفكر ولم يستطع أن يستنتج لم يظهر بهذا القدر الضعيف أمامها. وما الذي عليه فعله حين يقابلها، فقال لنفسه "فلأقبل يدها"، فلم يقبل يد أمه ولم يحضنها منذ سنوات. فمثل هذه العادات لا وجود لها في بيت رستم بيلفان. وما كانت

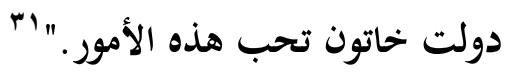

من هذا يتضح أن الكاتب حينما راح يتحدث عن أمومتها وطبيعتها الإنسانية نجده وقد

ذكر اسمها الأصلي "دولت خحاتون" وليس لقبها "باجي بي" الذي يعبر عن القوة والصلابة. مثلما اتضح فيما سبق عرضه لشخصية "دولت خحاتون" فإنها شخصية مثطورة عبر أحداث الرواية، كل أحداث الرواية تتمركز حولها، أو مرتبطة بها ارتباطاً وثيقاً، لذا تمثَّلت القوة

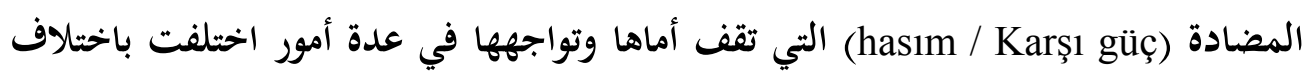
مراحل الرواية، فأولها ظهورها أمام القارئ كامرأة اسطورية يخشاها الجميع وذاع صيتها في كل مكان، تمسك في إحدى يديها السوط والقوس في اليد الأخرى. فكان ذلك في مواجهة

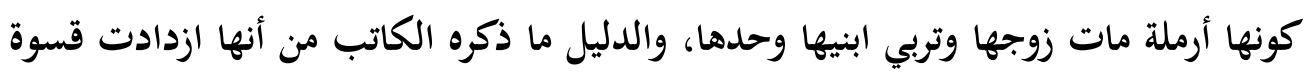
بعد وفاة زوجها. ثم يظهر صراعاً آخراً وهو الصراع مع ابنها ليصبح محارباً لا طالب علم. وتمر الأحداث ليكون الصراع الثالث لها في الرواية هو التماسك بعد خبر وفاة ابنها وعدم الانهيار، ثم طلب الثأر والبحث عنه، وحث ابنها الثاني نحو ذلك. وهي أيضاً من حيث البناء النفسي للشخصية داخل العمل الأدبي لا يمكن أن تكون شخصية بسيطة ( (kahraman مزيج من الشخصيتين معاً، فهي وإن كان من الصعب فهمها في بعض الأحيان، إلا أن القارئ كان يمكنه توقع تصرفاتها بصورة سليمة في أحيان أخرى كثيرة، فموقفها تجاه ابنها كريم

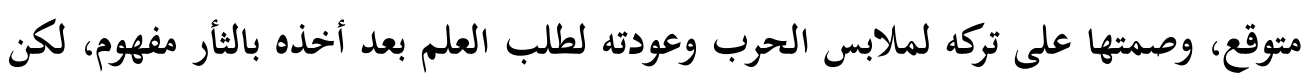
محاولتها إظهار التماسك أمام الجميع بعد مقتل ابنها يعتبر أمر مُبالغ فيه. فهي إذا شخصية بعدية

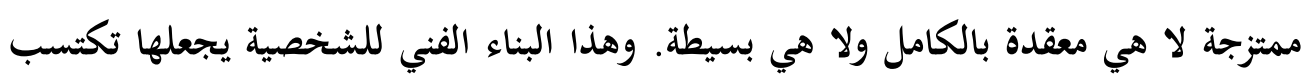
قرباً من نفسية القارئ نظراً لأن هذه هي الطبيعة البشرية في حقيقتها. وعلى النسق نفسه قام 
رسالة المشرة

\section{$\overline{r \varepsilon V}$}

الكاتب بتقديم شخصيتها والتعريف بها داخل الرواية من خلال المزج بين التقديم المباشر والديناميكي أو غير المباشر (Dlok Tanıtma)

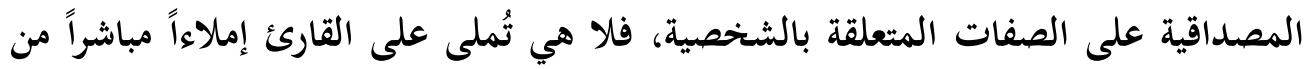

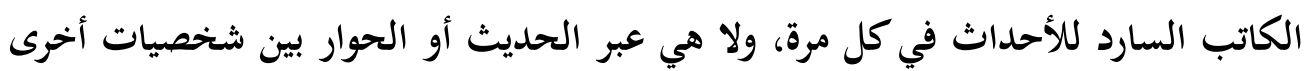

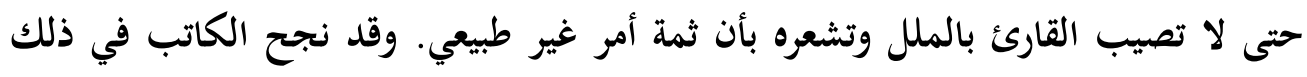
نجاحاً بالغاً إذا جعل بطلثه "دولت خحاتون" تضاهي الشخصيات التاريخية التي تدور الأحداث

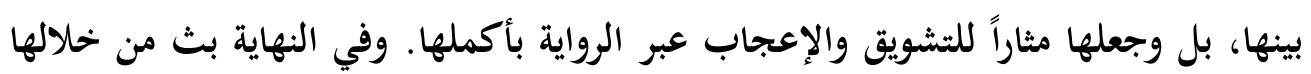

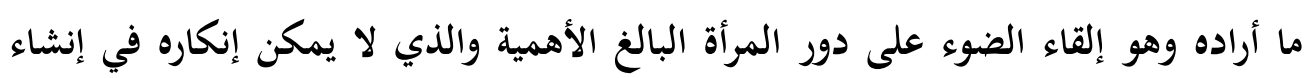
وتأسيس الدولة العثمانية.

والحقيقة أن أحد التجديدات التي أتى بها كمال طاهر على الرواية التركية هو إفساحه

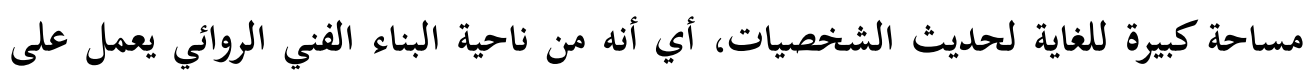

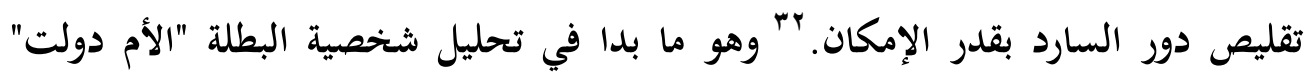

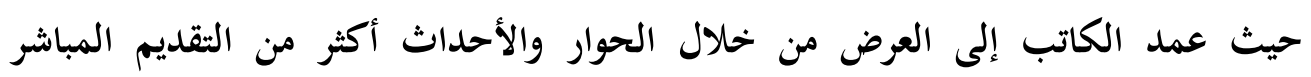

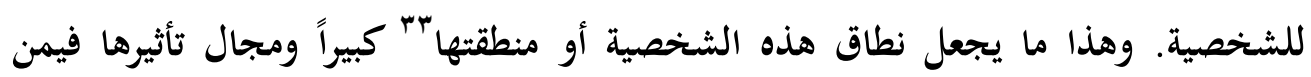

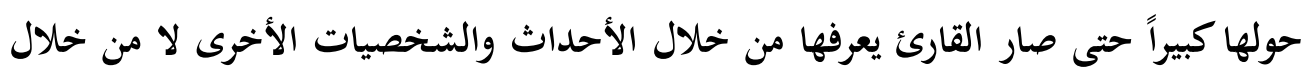
تقديم الكاتب/السارد لها.

\section{المبحث الثاني : "جوكتشه باجي" (GökçebacI) في رواية عثمانبك}

(Osmancik)

رواية "عثمانجيك" رواية تمثاز بالعدد الوفير من الشخصيات بها، وهي في أغلبها

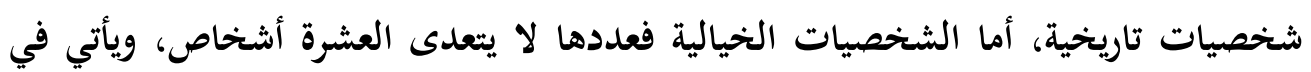

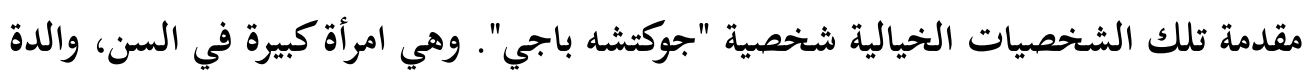

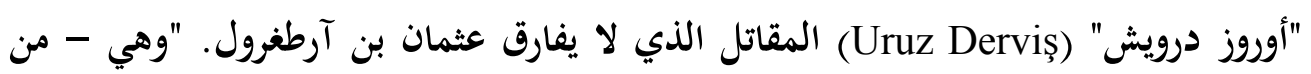

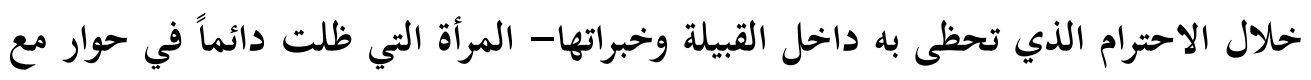


عثمان بن آرطغرول". «ّ ويأتي تعريفها داخل الرواية من خلالها هي، حيث تقدم نفسها على النحو التالي: "إن الذين يحبونني يطلقون عليّ دلي جوكتشه، ومن يقدرني يخاطبني بجوكتشه

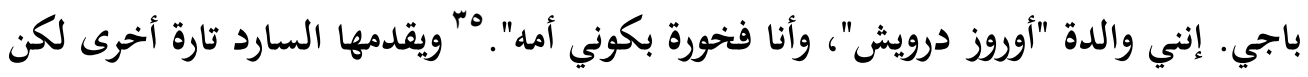
على لسان عثمان بن آرطغرول: "إنها امرأة مسنة لكنها عنيدة، وسمراء وهزيلة، ومع ذلك نشطة ومفعمة بالحياة.". ب فهي في نظر عثمان بن آرطغرول شخصية عنيدة ومفعمة بالحياة، أي أنها رغم سنها الكبير حينما تصر على شيء لا تهدأ إلا وتنفذه. ويبدو من خلال تعريفه لها أنها أدهشته ولفتت انتباهل، لذا سيظل مرتبطاً بها وفي حالة من الحوار المتواصل معها

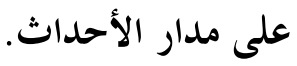
"جوكتشه باجي" شخصية رائدة داخل المجتمع. هي من تختار المكان الذي يتم فيه إنشاء القرية الجديدة، وتقف على رأس العمال، وتعمل معهم بنفسها: "لقد رأينا أن نقيم

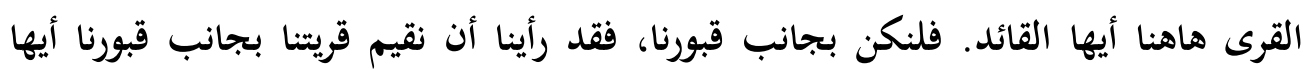
القائد، ولا نترك شهدائنا بمفردهم. فلقد رأينا أن نسعدهم بأن نجعل الأولياء رفقاء لهم. كانت تمسك بمجرفة في يدها، فأمسك عثمان بك بالمجرفة وأخذها، وذهب إلى موضع

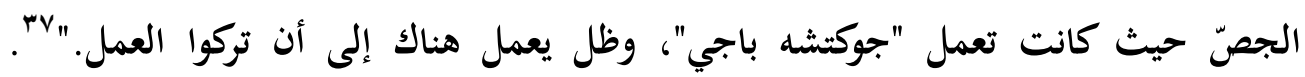
فاختيارها لمكان القرية بالقرب من المقابر وسعيها لذلك إنما من أجل أن يظل القوم محافظين على ما سار عليه الآباء والأجداد، وهي تفعل ذلك عن قصد وفهم كامل لما تقصده.

أما عن دورها مع عثمان بن آرطغرول، فكان لها بالغ الأثر جنباً إلى جنب مع الثيخ "آده بالي ^^" (Ede Bal1) في تحول اهتماماته وتغيرشخصيته على النحو الذي يجعله يحل محل والده في قيادة العشيرة. بل كانت هي الأكثر ايماناً بقدراته وصفاته التي تؤهله للقيادة، ولا

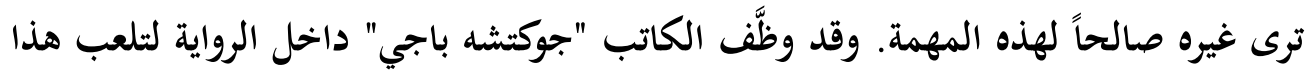
الدور، فكانت هي الملقن لعثمان بن آرطغرول دائماً بأنه الأجدر من أخيه لزعامة القبيلة،

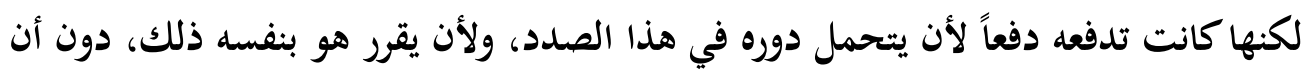


(سالة المشرة

$r \varepsilon q$

يُفرض عليه. "أيا عثمان الصغير، أصدقني القول، أصحيح ما قاله ابني "أوروز"؟ ألا تريد أن

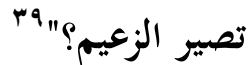

يتضح موقفها هذا من تنصيب عثمان بن آرطغرول وجعله زعيماً على القبيلة، أو الدور الذي وظفها إياه الووائي داخل العمل الأدبي أكثراً فأكثر، حتى صار هذا الموقف هو القوة المضادة التي تقف أمام البطلة، أو التي طالما سعت البطلة لتحقيقه. وحينما شعر عثمان بن آرطغرول بجلل المهمة والحيرة في نفس الوقت لم يذهب لأبيه ولا للشيخ "آده بالي"، إنما ذهب إلى "جوكتشه باجي" ليسألها، وكأنها هي الأقرب إليه من نفسه، إيماناً منه بأنها قادرة من خلال حكمتها وخبرتها على قراءة قدراته الخفية، والكاتب حينئذٍ يجعله يخاطبها بالأم للدلالة على مدى قربها منه أيضاً كالتالي: "يا أماه جوكتشه. قالها بصوت أجش لكن حميمي. أخبريني الصدق فالإجابة الصادقة على سؤالي ليست موجودة سوى لديك أنت فقط: هل

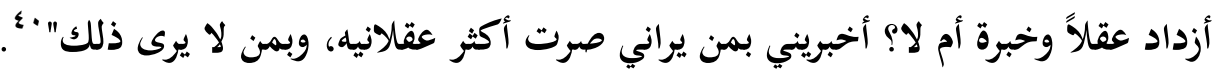
أما مشهد وفاتها في نهاية الرواية فكان هو الآخر خير دليل على مدى حبه حبها لوطنها وفدائها له بنفسها، بل وشاهد في الرواية على مشاركة المرأة للرجل في كل المناسبات آنذاك، إذ كانت تسير في الصفوف الأولى للقافلة التي يرأسها "عثمان بن آرطفرول" والمتوجهة إلى "بيلاجيك" (Bilecik) بناء على دعوة من قائدها، والذي كان قد أعد فخحاً لقتل "عثمان بن آرطفرول"، وبالفعل تأتي سهام الغدر ليسقط سبعة من القافلة قتلى من بينهم امرأتين، وكانت "جوكتشه باجي" إحدى هاتين الامرأتين. وقد صور الكاتب هذا المشهد بصورة تؤكد على أهمية هذه المرأة داخل المجتمع، حيث لم يذكر أي من القتلى الآخرين أو يشير إليه ولو بإشارة بسيطة، كما أنه قدم هذا المشهد للقارئ على أنها ليست امرأة عادية، مع ابراز مدى تأثر "عثمان بن آرطفرول" بوفاتها وتذكره لكلماتها وبكائه عليها كالتالي: "تم دفن جوكتشه باجي وباقي السبعة شهداء والتي منهم امرأة أخرى بملابسهم تحت شجرة دلب ضخمة واقعة على بعد خمسة عشر أو عشرين خطوة من الباب الذي دخلوا 
وبينما كانت جوكتشه باجي يواريها الثرى فلم يكن الباكي عليها بحرقة هو ابنها "أوروز

درويش" ولا حفيدتها "أي بيكا"، إنما كان الغازي "عثمان خان".

شَعَر عثمان الغازي وكأنه في "هارلاق". وصوت "جوكتشه باجي" يدوي في وادي "هارلاق"، وصار وكأنه يأتي حتى هنا:

"إنني أتمنى أن يصير عثمانجيك هو القائد عثمان، وألا ينعزل القائد عثمان عن

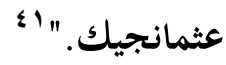

أخر ما يتذكره "عثمان بن آرطفرول" ويدور في ذهنه من كلمات "جوكتشه باجي" هو وصيتها له بألا يترك الإمارة لأنه الأحق بها، وألا ينسى صفاته الحميدة الموجودة في شخصيته البسيطة كذلك، والذي يدلل أيضاً على مدى تأثره بها كشخصية كان لها أكبر أثر في نفسه. إذا ومن خحلال ما سبق فإن الروائي طارق بوغرا قام بتقديم شخصيته "جوكتشه باجي" من

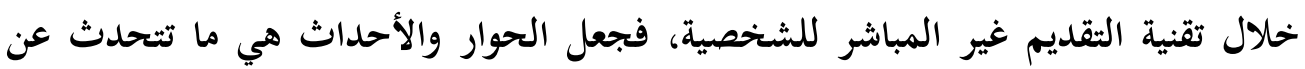
البطلة وتصف شخصيتها، ومع ذلك فلم يطل الكاتب ويسهب في هذه التقنية بالصورة التي تفقد هذه الشخصية مصداقيتها لدى القارئ، خصوصاً أنها وسط شخصيات تاريخية عديدة، والتي كانت بلا أدنى شك تحمل دور الفتوحات والعمل على توسيع رقعة الدولة، إلا أنه الكاتب/السارد- منح لهذه الشخصية النسائية دون غيرها وظيفة الحفاظ على الهوية التركية من الضياع من خلال مراعاة التقاليد وإنشاء المجتمع عليها وعدم ترك فرصة للأحداث التاريخية المتلاحقة من أن تجعل القوم ينسون ماضيهم وتراثهم.

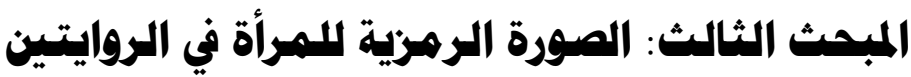

"استخدام الرمز - كأداة فنية لإثراء العمل الأدبي - قديم في الأدب، وعلى قدر ذكاء

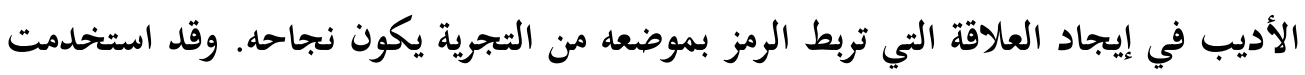

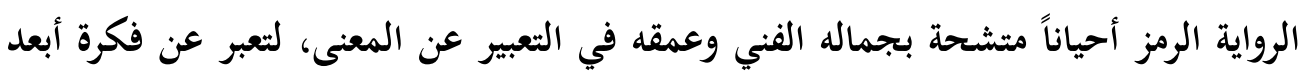
مما توحي به الحكاية في الرواية." ؟ وفيما يلي عرض للصورة الرمزية لشخصية "الأم دولت" و "جوكتشه باجي" في الروايتين. 
رسالة المشرة

YOI

أ- الأم دولت "Devlet Ana"

لقد ذكر كمال طاهر في حوار أجراه بنفسه عن أنه لم يقصد الإشارة إلى الأحداث ولا

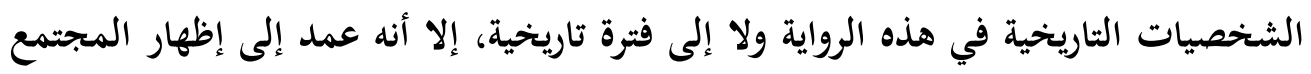

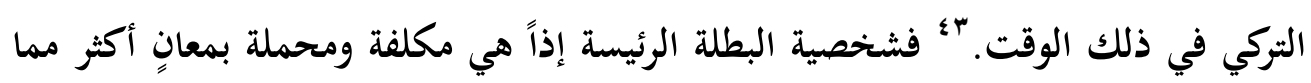

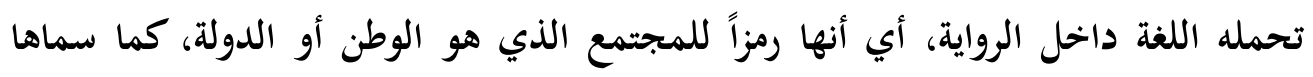

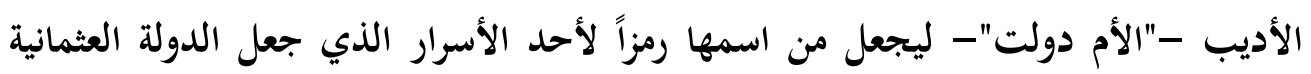

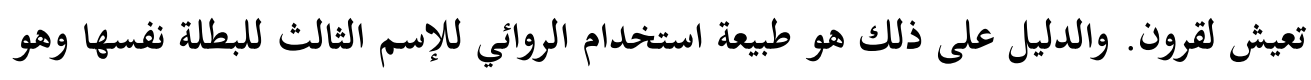

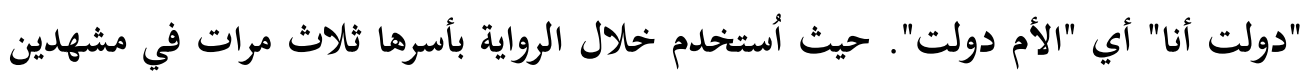

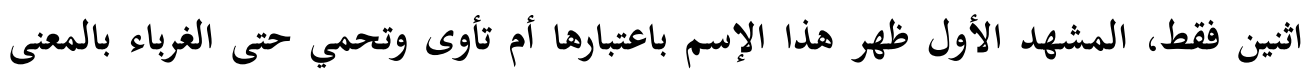

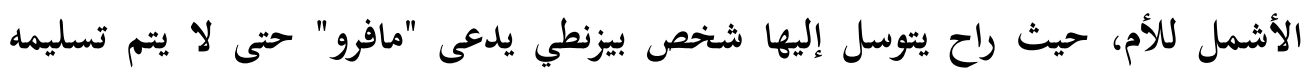

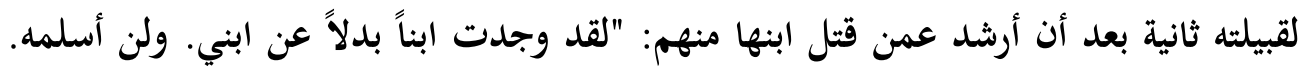

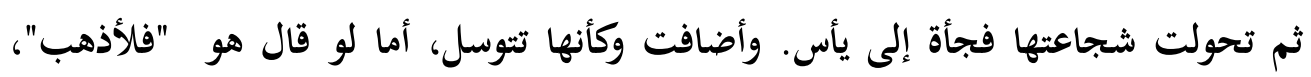
فهذا أمر آخر.

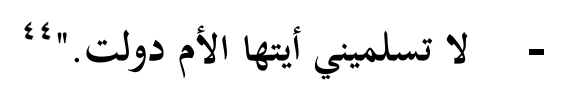

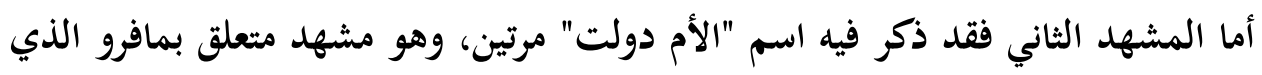

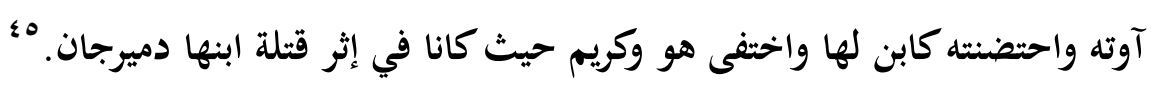

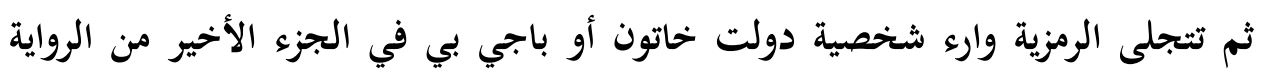

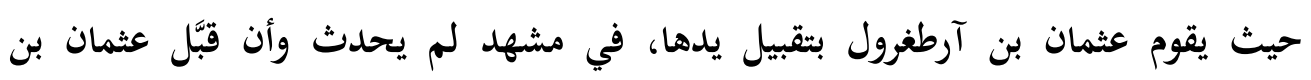

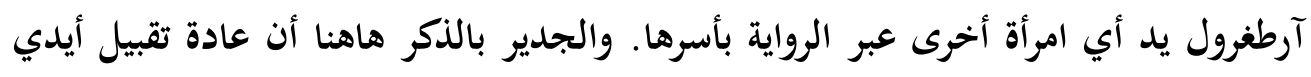

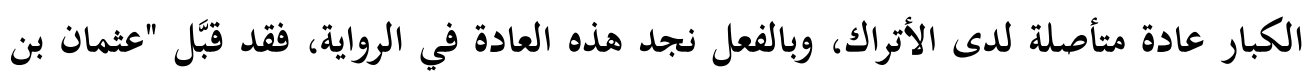

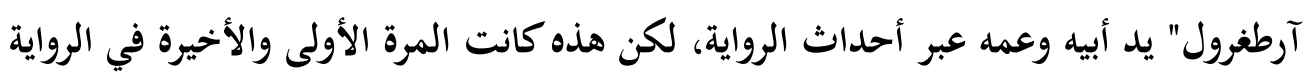

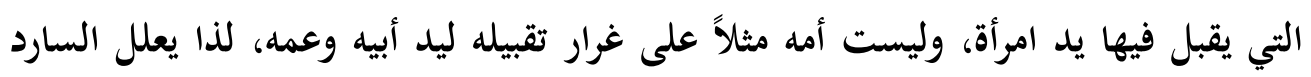

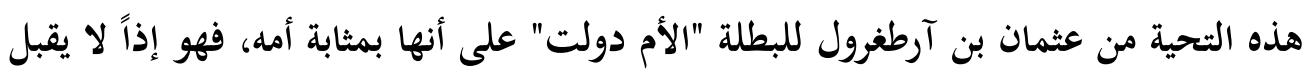


يد "الأم دولت" فحسب، إنما هي الأم الكبرى التي شملت القبيلة بأسرها، وحلمت الدولة على أكتافها: "قام عثمان بك بتقبيل يد "باجي بي" التي في مكانة والدته دون تردد ولا

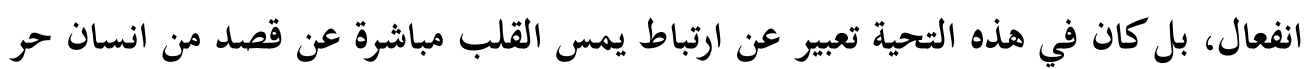
واثق من نفسه." "؛ والواضح هنا أن السارد أكد أن هذه التحية هي ارتباط وعن قصد وكأنه يشير إلى الوطن. فهي الأم الإعتبارية عبر أحداث الرواية ليس لعثمان بن آرطغرول فحسب، إنما لكل شخص يلجأ إليها، وللمجتمع ككل.

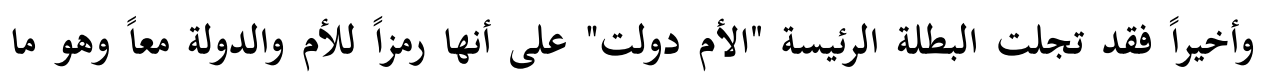

$$
\text { يتضح من اسم الرواية المسماة على اسمها. }
$$

\section{ب- جوكتشه باجب "Gökçebacı"}

الصورة الرمزية للمرأة في رواية "عثمانجيك" مثلتها شخصية "جوكتشه باجي" وحدها دون غيرها، حيث أراد الكاتب أن يخلع عليها وحدها رمزية الأم في قدسيتها واحترام الجميع لها، واحتوائها هي للجميع.

على نفس نمط رواية "الأم دولت"، وفي مشهد يكاد يكون متطابق لها، يأتي عثمان بن آرطفرول ليقبل يد "جوكتشه باجي"، فبعد عودته من سفره وتوجهه إلى القوم بصحبة زوجته

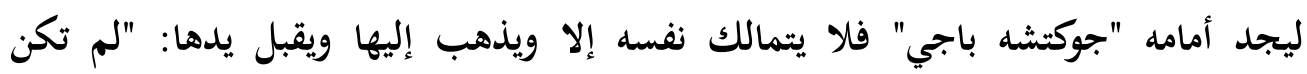
"جوكتشه باجي" هي أول من رأتهم، لكنها كانت أول من عرفتهم، فتوقفت، وكان مازل فيما بينهما مسافة خمسة أسهم، إلا أنها نادت بصوتٍٍ عالٍ قائلة:

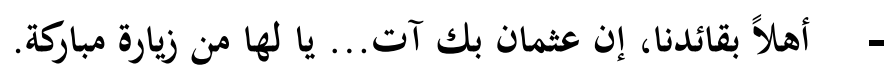

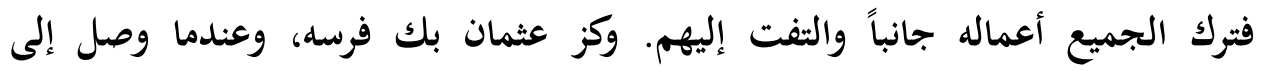
السهل، قال وهو ينزل إلى الأرض:

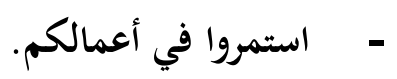

وبينما راح الجميع ينفذ ما طلبه منهم، قام "عثمان" بتقبيل يد "جوكتشه باجي". v؛ 
رسالة المشرتة

\section{$\overline{Y O Y}$}

واللافت للانتباه أن "عثمان بن آرطغرول" لم يقبل يد أي امرأة غير "جوكتشه باجي" عبر

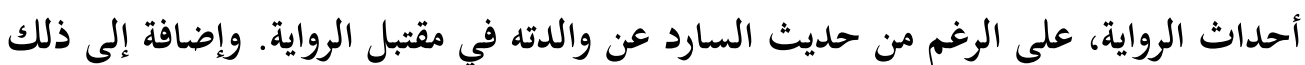

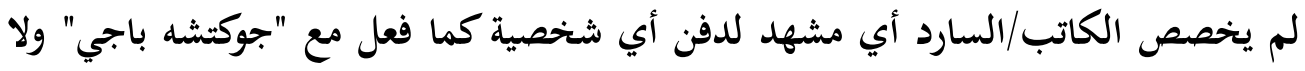

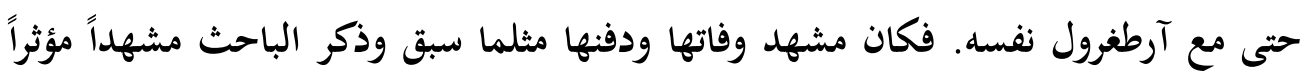

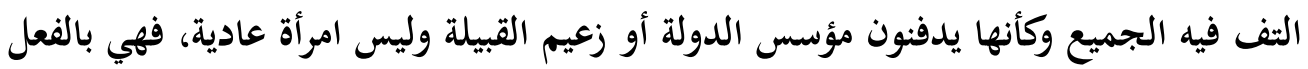

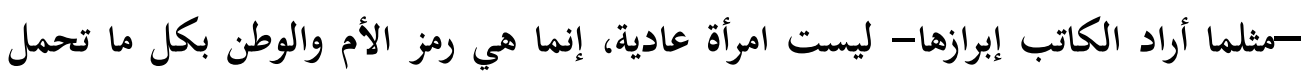

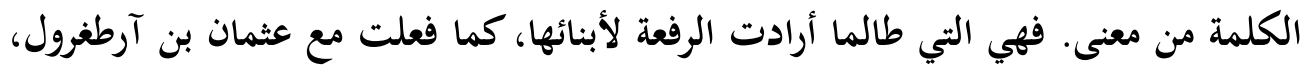

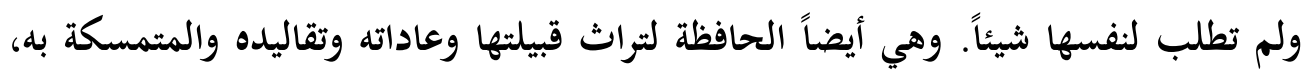

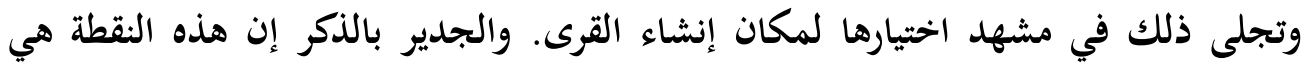

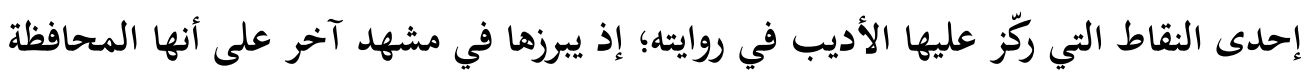
لعهود الأباء ولو بعد رحيلهم. فحينما جاء قوم ونزلوا على القبيلة وراحت هي وابنها "أوروز

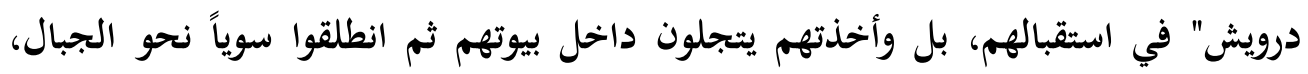

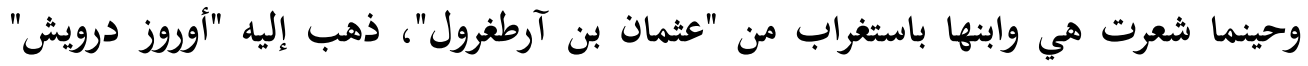

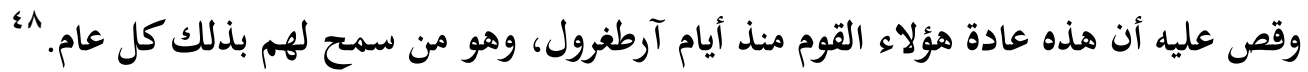

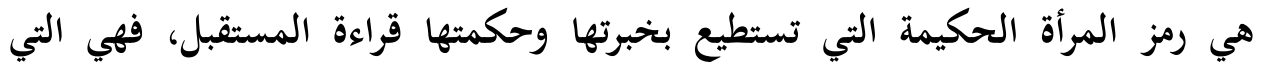

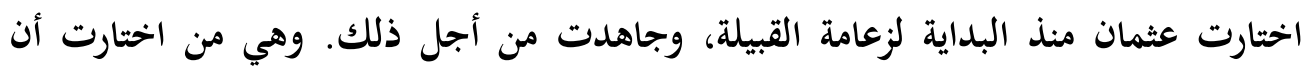
تكون القرى الجديدة بجانب مقابر الشهداء، حتى لا ينس الجيل الجديد أبائهم وأجدادهم

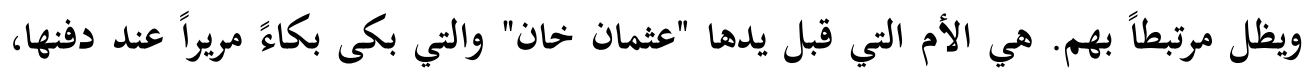

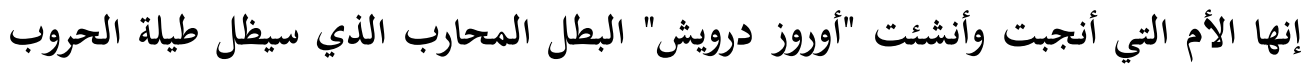
بجانب عثمان بن آرطغرول، وهي المرأة التي تقدرها وتحترمها "مالهوم خاتون" زوجة عثمان الغازي وتسعى لإرضائها، بل وعرضت على عثمان الغازي أن تكون حفيدة جوكتشه باجي الغي

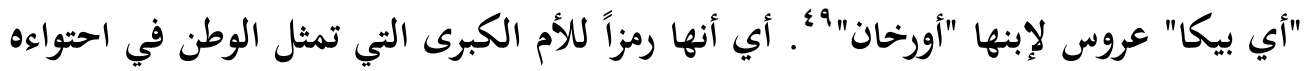

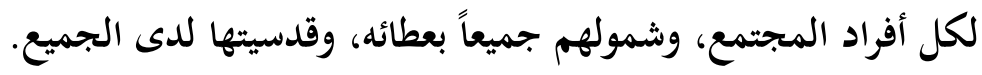


لم تكن المرأة إذاً في تلك الفترة كما رأينا في الرواية السابقة نموذج لمعشوقة أو محبوبة خليلة، إنما كانت امرأة أم ومحاربة وأم لمحارب، أي أن دورها لم يتوقف عند دور الأم داخل الأسرة الصغيرة والذي أدته كل منهما بنجاح، إنما تخطاه ليشمل المشاركة الفعالة داخل المجتمع ككل بل والتأثير فيه أبلغ الأثر، حتى صارت كل من "دولت خحاتون" في رواية "الأم دولت" و"جوكتشه باجي" في رواية "عثمانجيك" أماً لأفراد المجتمع بأسره، تحتوي أفراد القبيلة أو المجتمع الذي تعيث وسطه، وتؤثر فيه أيما تأثير. فكانت كل منهما وطناً يأوى الخائف الملهوف وقت الخطر، ويحتوي السائل الحيران عند الشدة.

النغاتمهة:

رواية كمال طاهر (Devlet Ana) تحمل اسم شخصية البطلة "دولت أنا" أو "الأم دولت" وذلك على الرغم من أنها تتناول فترة إنشاء الدولة العثمانية على يد عثمان بن آرطفرول والبطل الرئيس لهذه الرواية هو عثمان بن آرطفرول نفسه. ومما لا شك فيه أن هذه التسمية ليست مصادفة أو لا معنى لها، إنما هي نابعة عن رسالة الكاتب التي أراد إيصالها للقارئ والتي مفادها أن المرأة لها دورها المهم جنباً إلى جنب مع أعلى رأس في الدولة العثمانية في إنشاء وتأسيس هذه الدولة، وذلك في إثارة منه إلى الدور الذي لعبته المرأة في تلك الفترة والتي لا يشار إليها في كتب التاريخ.

تمثلت شخصية المرأة "البطلة" التي صورتها الرواية في صورة "دولت خحاتون" والتي تمثل نساء تلك الفترة بأنها شخصية قوية، صلبة، تراعي العرف والعادات، تستهدف بناء أمتها وليس أسرتها فحسب، وتبذل التضحيات من أجل ذلك. أما شخصية جوكتشه باجي (Gökçebac1) في رواية عثمانجيك (Osmancık) فهي الأم التي أنشأت وربَّت المقاتل الواقف إلى جانب "عثمان بن آرطغرول" في كل معاركه، وجاهدت

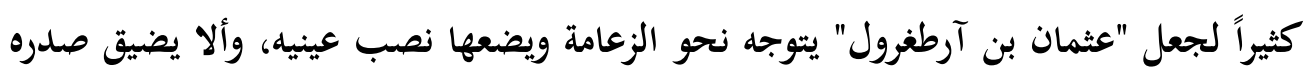
بمن لا يراه قادراً على ذلك، وفي شحذ قدراته نحو هذه الزعامة. ولم تكل عن العمل داخل مجتمعها رغم سنها الكبيرة، وماتت وهي تؤدي وظيفتها كأي امرأة أخرى داخل هذا 
رسالة المشرة

\section{Yo0}

المجتمع. فكانت رائدة في حياتها بأفكارها وشخصيتها الرائدة، وفي مماتها حينما سقطت قتيلة بسهام الغدر وهي في مقدمة أفراد قبيلتها.

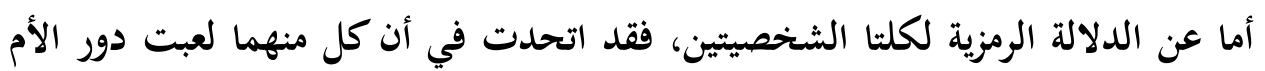
داخل الرواية، لكن ليس لأبنائها فحسب إنما لكل أفراد القبيلة، وكأنها في ذلك الوطن في حبه ورعايته وعطاءه لكل أبنائه. فكل من "دولت خحاتون" و "جوكتشه باجي" شخصية نامية ترتبط بها الأحداث وتنطور معها، ومن ناحية أخرى خلع كل روائي على شخصيته النسائية تلك رمزية الوطن في قدسيته واحترامه. وأخيراً يرجو الباحث أن يكون قد وُفق فيما رمى إليه في بداية الدراسة من تحليل الثخصية النسائية وإظهار دورها في هذه الفترة البالغة الأهمية من تاريخ الأتراك. أما عن لئن توصيات الدراسة فيجد الباحث أن عنصر المكان في رواية عثمانجيك لطارق بوغرا يستحق الدراسة لما فيه ثراء فني، إذا عمل الكاتب على ربط المكان بالزمان والإنسان بصورة بارعة.

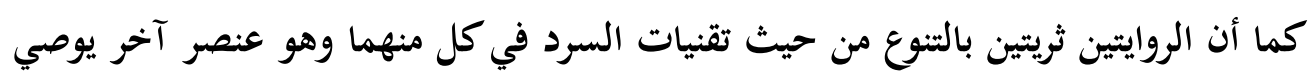

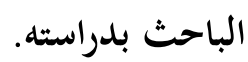


طارق بوغرا (191^- \991): أحد أهم وأشهر أدباء في العصر الجمهوري، كتب القصة والرواية

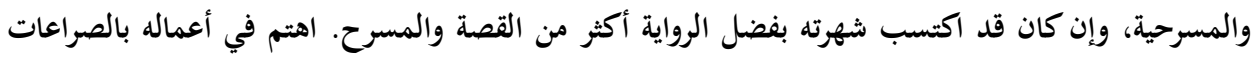

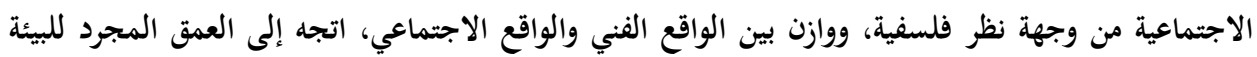

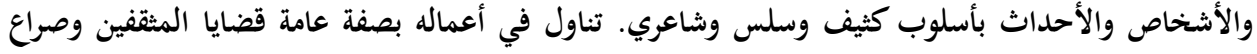

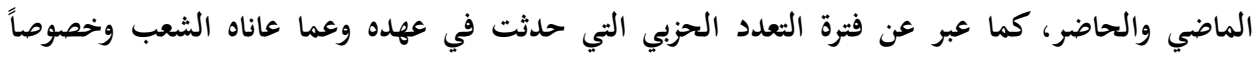

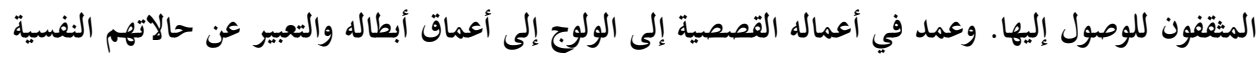

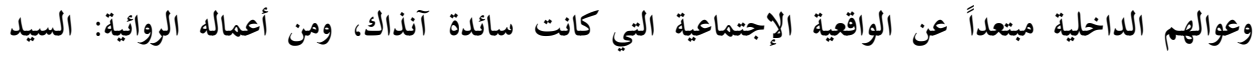

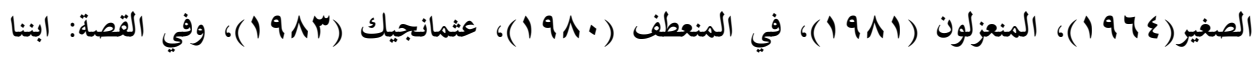

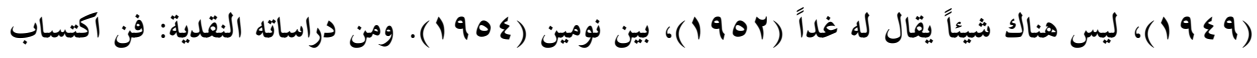

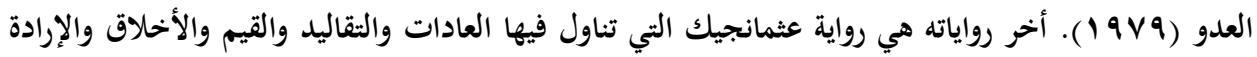
التي صنعت دولة كبرى من قبيلة.

- Ramazan Korkmaz (Editör), Yeni Türk Edebiyatı 1839-2000, Grafiker Yayınları, Ankara, 2. Bask1, 2005, s: 335-336; 457-459

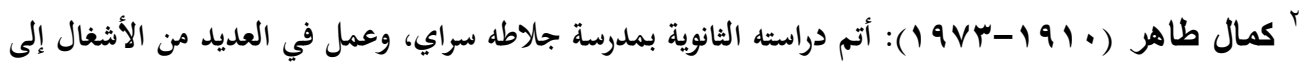

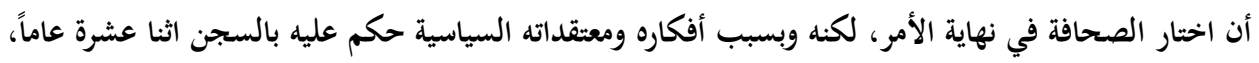

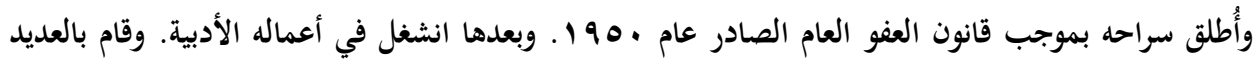

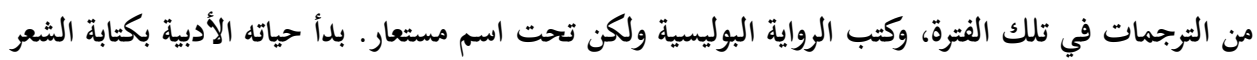

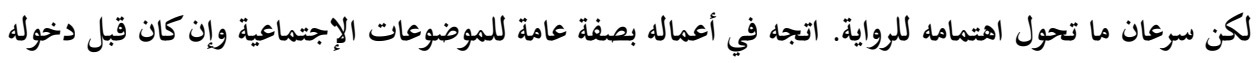

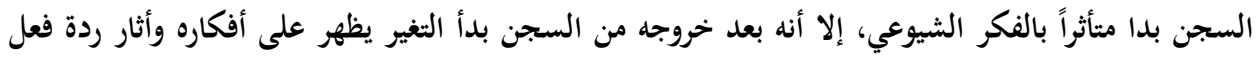

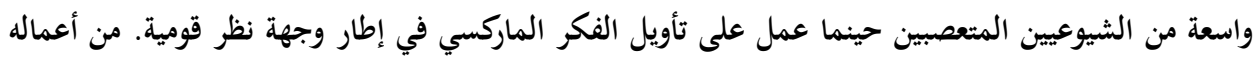

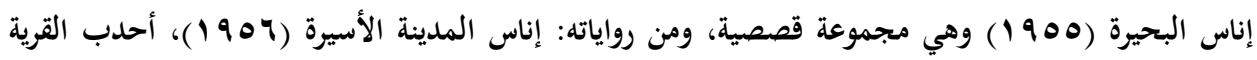

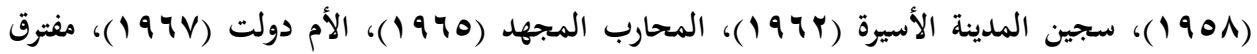

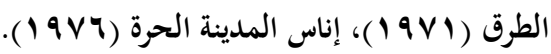

- Önder Kemal, Yazarlar ve Şairler Sözlüğü, İkılâp Yayınları, İstanbul, 2001, s: 241-242;

Arslan Tekin, Edebiyatımızda İsimler ve Terimler, Ötüken Yayınları, Ankara, 1995, s: 372-373

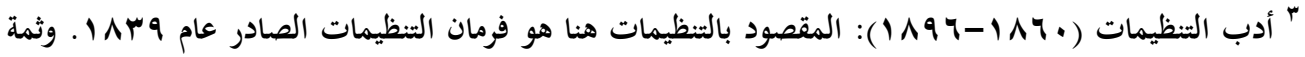

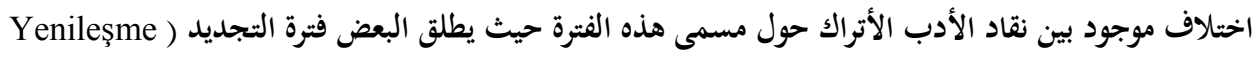
(Dönemi 


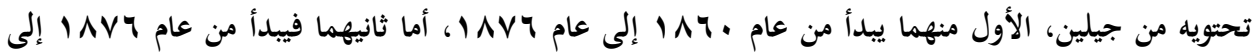
عام 1/99، لذا يطلق البعض الأخر على نفس هذه الفترة مسمى الأدب التركي ما بعد التنظيمات

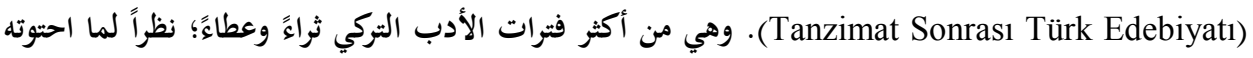

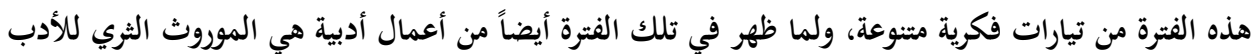
التركي الحديث على مدار فتراته المتلاحقة الأخرى، ناهيك عما شهدته هذه الفترة من أدباء وشخصيات كان التهان

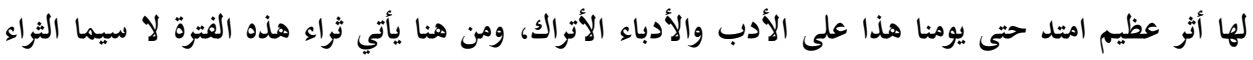
الفكري.

- Kâzım Yetiş, Dönemler ve Problemler Aynasında Türk Edebiyatı, Kitabevi Yayınları, İstanbul, 2007, önsöz

يذكر أيضاً "توران قاباتش" في كتابه "معجم المصطلحات الأدبية" أن تسمية هذه الفترة بأدب التنظيمات هي تسمية خاطئة؛ وذلك لأنه إذا كانت هذه الفترة أخذت اسمها من فرمان التنظيمات الصادر في عام

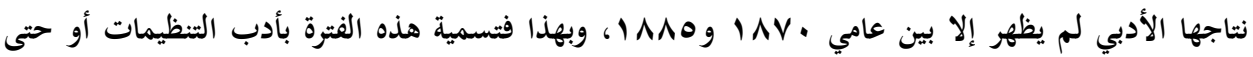

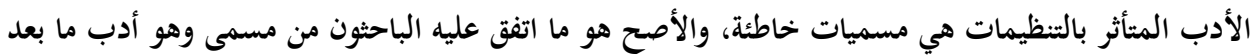

$$
\text { النظيمات أو فترة الإحياء. أنظر: }
$$

- Turan Kabataş, Ansiklopedik Edebiyat Terimleri Sözlüğü, Akçağ Yayınları, Ankara, Genişletilmiş ikinci bask1, 2004, s. 448

4 Melin Haser, Tanzimat devri Türk romanında kadın kahramanlar, İstanbul Üniversitesi, Sosyal Bilimler Enstitüsü, Türk Dili ve Edebiyatı Bilim Dall, Yeni Türk Edebiyatı Anabilim Dall, Yayınlanmamış Doktora Tezi, 1994, 551 s.

${ }^{5}$ Ayşe Mungan Başkal, Mustafa Kutlu Hikâyeliğinde Kadın, Gazimostafa Paşa Ün., Sosyal Bilimler Enstitüsü, Türk Dili ve Edebiyatı Ana Bilim Dalı, Yeni Türk Edebiyatı Bilim Dalı, Yüksek Lisans Tezi, 2010, 193 s.

${ }^{6}$ Hilal Doğan, Kemal Tahir'in romanlarında kadın kahramanlar, Selçuk Üniversitesi, Sosyal Bilimler Enstitüsü, Türk Dili ve Edebiyatı Bilim Dal, Yeni Türk Edebiyatı Anabilim Dal, Yayınlanmamış Yüksesk Lisans Tezi, 2008, $243 \mathrm{~s}$.

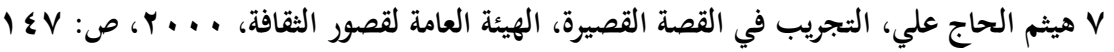

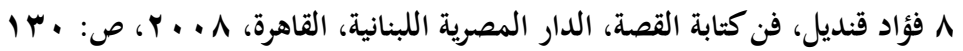

9 İsmail Çetişli, Metin Tahlillerine Giriş / 2 (Hikâye-Roman-Tiyatro), Akçağ Yayınları, Ankara, 2004, s: 66

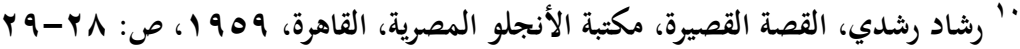

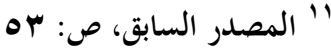

$$
\begin{aligned}
& \text { r" عبد الله مرتاض، في نظرية الرواية بحث في تقنيات السرد، عالم المعرفة، المجلس الوطني للنقافة والفنون }
\end{aligned}
$$

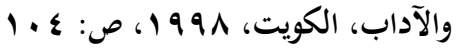

${ }^{13}$ İsmail Çetişli, s: 70

${ }^{14}$ İsmail Çetişli, s: 71 
• يُطلق على هذه الشخصية مصطلحاً آخراً وهو الشخصية المدورة، ويلتف الكثير من النقاد حول هذا المصلطح، ويطلقون عليها كذلك الشخصية المكثفة.

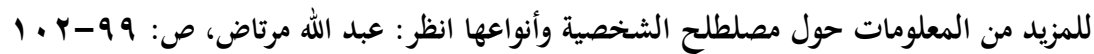

${ }^{16}$ Mehmet Tekin, Roman Sanatı I (Romanın unsurları), Ötüken Yayınları, İstanbul, Üçüncü Basım, 2003, s: 96-96; İsmail Çetişli, s: 68-69

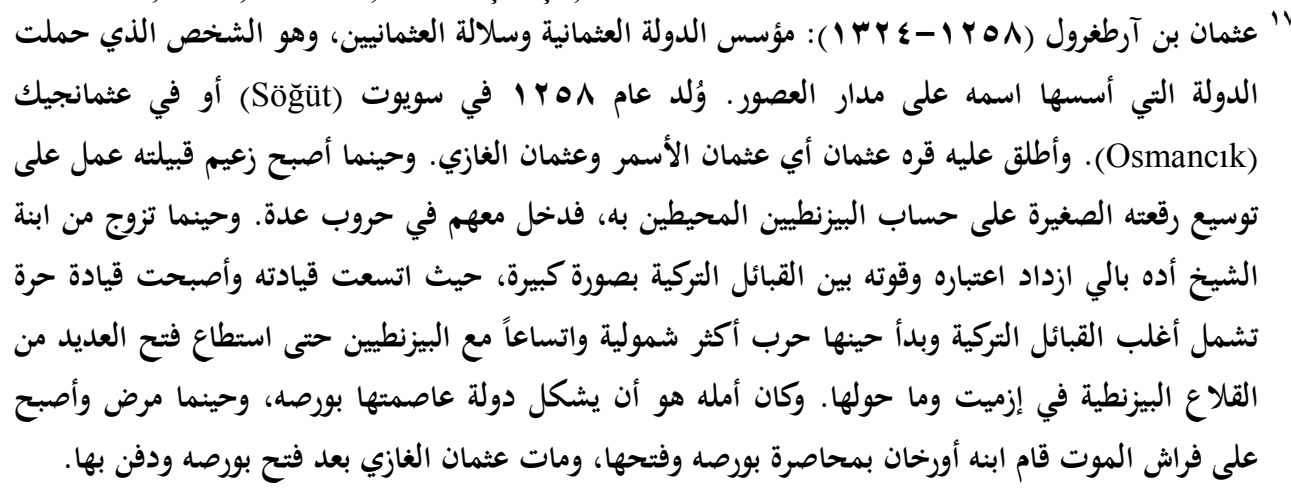

- "Birinci Osman (Gazi)" <madde>, Resimli Osmanlı Tarihi Ansiklopedisi, Midhat Sertoğlu, İstanbul Matbaası, 1958, s. 228-230

18 "Eniştemin anası... "İlle Müslüman olsun gelinim" diye direnmekte... İçini çekti. Ablam inattır, eniştemin anası dersen... "Bacıbey inadı" nam salmıştır, Konya'dan İstanbul'a..." Kemal Tahir, Devlet Ana, s: 12

$$
\begin{aligned}
& \text { 19 الغازي آرطغرول (؟ - I I I ) والد السلطان عثمان مؤسس الدولة العثمانية، ومعروف أنه منتسب لقبيلة قايي. }
\end{aligned}
$$

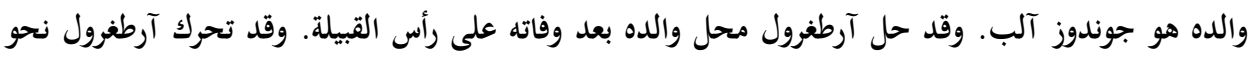

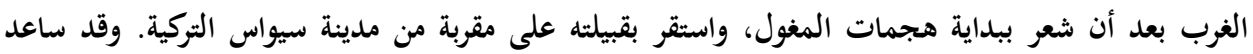

$$
\begin{aligned}
& \text { الجيش السلجوكي الذي كان يحارب في تلك المنطقة ضد المغول. وحينما انتصر السلاجقة أنعم عليه أميرهم }
\end{aligned}
$$

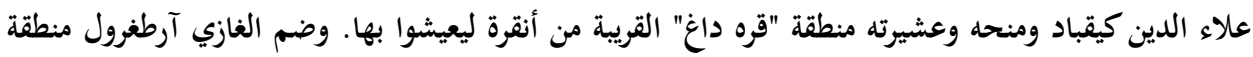

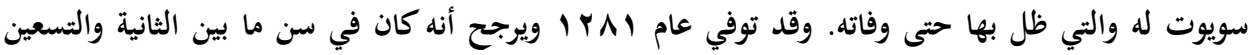

$$
\begin{aligned}
& \text { والسادسة والتسعين. ويقع ضريحه في سويوت التي تبعد بكليوا متراً واحداً عن بيلاجيك شمالأ الأ. }
\end{aligned}
$$

- "Ertuğrul Gâzi" <madde>, Osmanlı Tarihi Ansiklopedisi, İhlâs Matbaacılık ve Gazetecilik

Yayınları, İstanbul, 1989, c.3; M. Orhan Bayrak, Osmanlı Tarihi Sözlüğü, İnkilâp Yayınları, İstanbul, 1999, s: 129

20 "Karıları bile düvüşkendir Ertuğrul Bey'in... Bunlara "Rum bacıları" derler, başkanları, Demircan eniştemin anası Bacıbey'dir. Bunların töreleri de, gaziler, savaşçı dervişler töresi gibi, din yayma üstünedir. Anladın mı neden razılıkk vermemekte Bacıbey, Demircan enişteme?" Kemal Tahir, a.g.e., s: 17

21 "Rum Bacılardan başkan seçildi seçileli, "Bacıbey" diye çağrılan Devlet Hatun, uzun boylu, geniş gövdesiyle sanki Söğüt'ü depreme vererek geliyordu. Körpeliğinde ne kadar yakıcı güzel olduğu, iri kara gözlerinden, çekme burnundan, hiç örselenmemiş etli 
dudaklarından belliydi. Ok atmakta, mızrak savurmakta, kılıç tutmakta, binicilikte değme savaşçlardan geri kalmaz, hele

korkmazlıkta çoğunu yaya bırakırdı. Kocası Rüstem Pelvan'ın, inegöl toprağına yapılan bir akında ölmesinden bu yana, büsbütün sertleşmiş, Ertuğrul Bey'den başkasını dinlemez olmuştu. " Kemal Tahir, a.g.e., s. 83

22 "Bacıbey, Köslük Meydanı'na doğru kararlı adımlarla yürüdü." Kemal Tahir, a.g.e., s: 91

${ }^{23}$ Kemal Tahir, a.g.e., bkz., s: $94-97$

${ }^{24}$ Kemal Tahir, a.g.e., bkz., s: $91-94$

${ }^{25}$ Kemal Tahir, a.g.e., s: 86,422

26 "Çünkü karıları atlanınca, bunlar ölüm şerbetini peşin içermiş." Kemal Tahir, a.g.e., s: 17

${ }^{27}$ Kemal Tahir, a.g.e., s: 69

${ }^{28}$ Kemal Tahir, a.g.e., s: 91

${ }^{29} \mathrm{Kemal}$ Tahir, a.g.e., s: 137

${ }^{30}$ Kemal Tahir, a.g.e., bkz. s: $135-141$

31 "Söğüt bacılarının beyi, Devlet Hatun, oğullarına hem bilek, hem de yürek gücüyle babasızlığın boyun büküldüğünü hiç duyurmamıştı. Kağnının yanında dimdik yürürken neden kendisine o kadar güçsüz göründüğünü, Kerim gene çıkaramadı. Karşılaşınca ne yapması gerektiğini duraklayıp araştırdı. "Elini öperim" dedi. Yıllardır anasının elini öpmemiş, boynuna sarılmamıştı. Rüstem Pelvan'ın evinde yoktu böyle âdetler... Devlet Hatun sevmezdi sulusepken sırnaşıklığı." Kemal Tahir, a.g.e., s: 94

32 Taner Timur, Osmanl1-Türk Romanında Tarih, Toplum ve Kimlik, İmge Yayınları, Ankara, 2. Bask1, 2002, s: 208

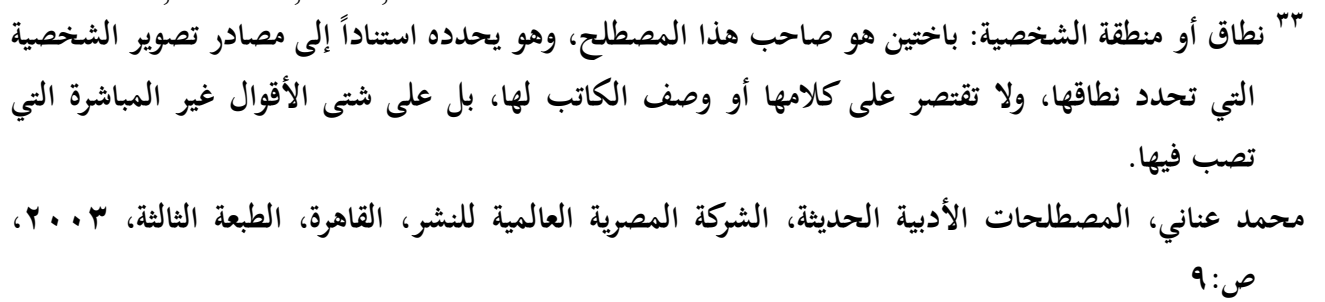

${ }^{34}$ A. Osman Dönmez, Osmancık Romanında Horasan Erenleri, Sızıntı, S. 327, Nisan 2006, s. 10

35 "Bana, sevenler Deli Gökçe, aşırı sayanlar da Gökçe bacı der. Uruz'un anasıyım; anası olduğumdan mutluyum.” Tarık Buğra, Osmancık, Ötüken Yayınları, İstanbul, 19. Basım, 2005, s: 102

36 "O biri, inadına yaşlıydı, kara kuruydu; ama diriydi, canlıydı." Tarık Buğra, s: 102

37 "Köyleri burada olsun dedik, beğ. Mezazarlarımıza sahip çıkalım, mezarlarımızın yanında köy yaşatalım dedik beğ. Şehitlerimizin yalnız bırakmayalım dedik. Vakti erenleri onlara yoldaş kılıp mutlandıralım dedik, beğ. Elinde bir kürek tutuyordu. Osman beğ, uzanıp aldı küreği. Ve gitti, Gökçe bacının çalıştığı kireç kuyusunda, iş bırakılana kadar çalıştı." a.g.e., s: 231

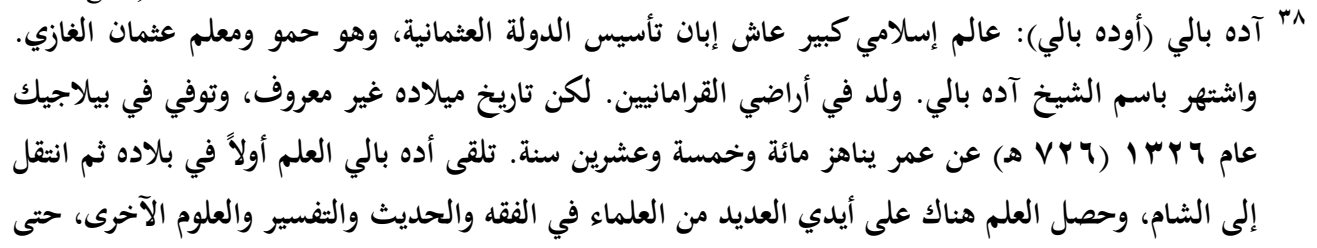




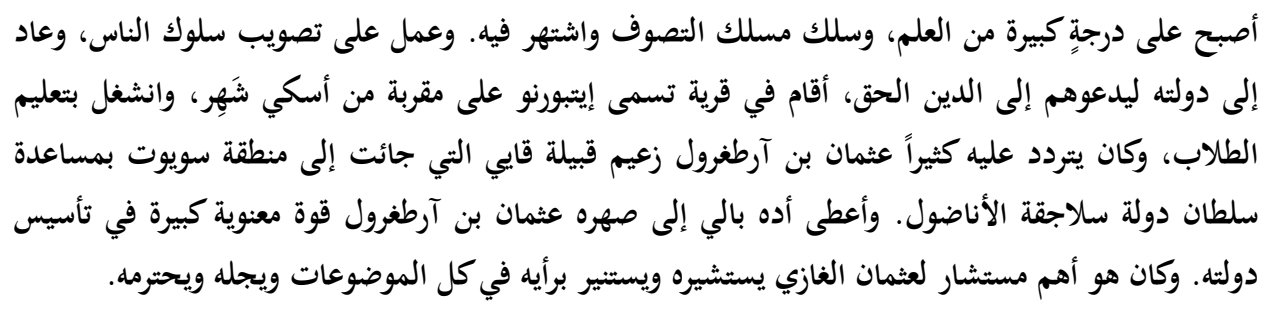

- "Edebâlî (Üdebâlîi)" <madde>, Yeni Rehber Ansiklopedisi, İhlâs Holding Yayınları, İstanbul, 1994, c.6

39 "Ey Osmancık; de bana bakayın: Benim Uruz'un dediğidoğru mudur? Sen beğ istemez misin?" Tarık Buğra, a.g.e., s: 104

40 "Gökçe ana, Gökçe ana dedi, tok, ama dost sesle; "Sen bana şunu dosdoğru söyle ki, soracağımın doğrusu ancak sendedir: Uslanır mıyım, uslanmaz mıyım ben? Uslanır deyenleri de, uslanmaz deyenleri de koy bir yana." Tarık Buğra, a.g.e., s: 105

41 "Gökçe bacı'nın üzerine son topraklar atıılırken gözleri dolu dolu olan oğlu Uruz Derviş değil, torunu Aybike değil, Osman Gazi hân'dır. Osman Gazi hân Harlak'te gibidir. Ve Gökçe bacı'nın sesi Harlak vâdisinde yankılanmakta, buralara kadar gelmekte gibidir: "Hey; dilerim Osmancık Osman beği koymaya, Osman beğ Osmancık'ten kopmaya." Tarık Buğra, a.g.e., s: 316

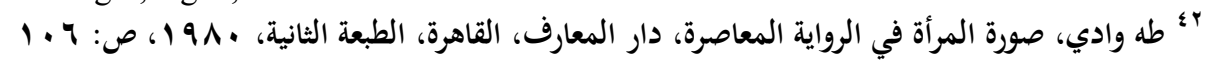

43 http://www.kirmizilar.com/tr/index.php/kultur-sanat-yazilari/3086-devlet-ana-veosmancik-romanlarinda-tasvir-edilen-osman-bey-in-psikolojik-portresi

44 "Oğlumun yerine oğul buldum! Vermem! Birden kabadayıllğı umutsuzluğa döndü. Yalvarır gibi ekledi. Kendi "Giderim" derse, o başka... -Gitmem, hayır! Öldürürler bunlar beni... Kırbaçladılar sabaha kadar. Verme beni, Devlet Ana!" Kemal Tahir, a.g.e., s: 141

${ }^{45}$ Kemal Tahir, a.g.e., s: 454

46 "Osman Bey, anası yerindeki Bacıbey tutup elini öpseydi ne bu kadar şaşırır, ne de bu kadar duygulanırdı. Bu selamda doğruca yüreğe dokunan, erkekçe güven, hür bir insanın isteyerek bağlanışı vardı." Kemal Tahir, a.g.e., s: 315

47 "Onları ilk gören değil, ama ilk tanıyan Gökçe bacı oldu. Aralarında daha beş ol atımı mesafe vardı; gene de sesini ulaştırdı: - Hey benim beğim, Osman beğ gelir.. o ne kutlu geliştir." Herkes işini bırakmış onlara dönmüştü. Osman beğ Al-1şığ mahmuzladı. Düzlüğe varınca da, yere konarken; - "Koman işinizi" dedi. Onlar sözüne uyarken, Osman beğ Gökçe bacının elini öptü." Tarık Buğra, a.g.e., s: 231

${ }^{48}$ Tarkk Buğra, a.g.e., s: 136

${ }^{49}$ Tarık Buğra, a.g.e., s: 285 


\section{قائمئة الإسادر}

أولاً : الصسادر العربية

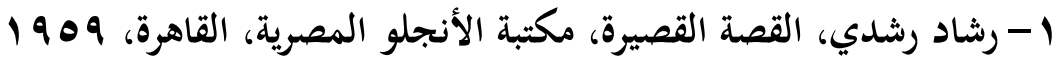

r- طه وادي، صورة المرأة في الرواية المعاصرة، دار المعارف، القاهرة، الطبعة الثانية،

$19 \Lambda$.

ץ-عبد الملك مرتاض، في نظرية الرواية بحث في تقنيات السرد، عالم المعرفة،

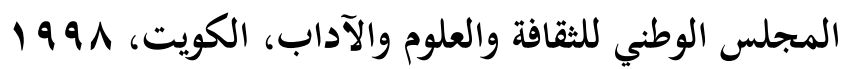

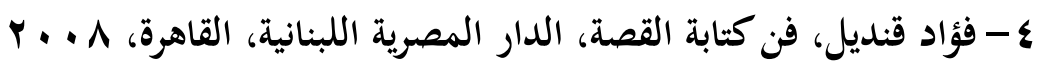

ه-محمد عناني، المصطلحات الأدبية الحديثة، الثركة المصرية العالمية للنشر،

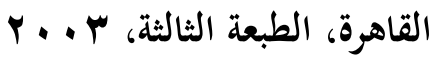

צ- هيثم الحاج علي، التجريب في القصة القصيرة، الهيئة العامة لقصور الثقافة، .. F.

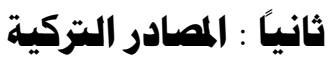

1- A. Osman Dönmez, Osmancık Romanında Horasan Erenleri, Sızıntı, S. 327, Nisan 2006

2- Arslan Tekin, Edebiyatımızda İsimler ve Terimler, Ötüken Yayınları, Ankara, 1995

3- Ayşe Mungan Başkal, Mustafa Kutlu Hikâyeliğinde Kadın, Gazimostafa Paşa Ün., Sosyal Bilimler Enstitüsü, Türk Dili ve Edebiyatı Ana Bilim Dalı, Yeni Türk Edebiyatı Bilim Dalı, Yüksek Lisans Tezi, 2010

4- Hilal Doğan, Kemal Tahir'in romanlarında kadın kahramanlar, Selçuk Üniversitesi, Sosyal Bilimler Enstitüsü, Türk Dili ve Edebiyatı Bilim Dalı, Yeni Türk Edebiyatı Anabilim Dalı, Yayınlanmamış Yüksesk Lisans Tezi, 2008

5- İsmail Çetişli, Metin Tahlillerine Giriş / 2 (Hikâye-Roman-Tiyatro), Akçağ Yayınları, Ankara, 2004

6- Kâzım Yetiş, Dönemler ve Problemler Aynasında Türk Edebiyatı, Kitabevi Yayınları, İstanbul, 2007

7- Mehmet Tekin, Roman Sanatı I (Romanın unsurları), Ötüken Yayınları, İstanbul, Üçüncü Basım, 2003 
8- Melin Haser, Tanzimat devri Türk romanında kadın kahramanlar, İstanbul Üniversitesi, Sosyal Bilimler Enstitüsü, Türk Dili ve Edebiyatı Bilim Dalı, Yeni Türk Edebiyatı Anabilim Dalı, Yayınlanmamış Doktora Tezi, 1994

9- M. Orhan Bayrak, Osmanlı Tarihi Sözlügü, İnkilâp Yayınları, İstanbul, 1999

10-Midhat Sertoğlu,Resimli Osmanlı Tarihi Ansiklopedisi, İstanbul Matbaas1, İstanbul, 1958

11-Osmanlı Tarihi Ansiklopedisi, İhlâs Matbaacılık ve Gazetecilik Yayınları, İstanbul, 1989

12- Önder Kemal, Yazarlar ve Şairler Sözlüğü, İkılâp Yayınları, İstanbul, 2001

13- Ramazan Korkmaz (Editör), Yeni Türk Edebiyatı 1839-2000, Grafiker Yayınları, Ankara, 2. Bask1, 2005

14- Tarık Buğtra, Osmancık, Ötüken Yayınları, İstanbul, 19. Basım, 2005

15-Turan Kabataş, Ansiklopedik Edebiyat Terimleri Sözlügü, Akçağ Yayınları, Ankara, Genişletilmiş ikinci baskı, 2004

16- Yeni Rehber Ansiklopedisi, İhlâs Holding Yayınları, İstanbul, 1994

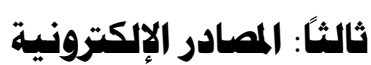

1- http://www.kirmizilar.com/tr/index.php/kultur-sanat yazilari/3086devlet-ana-ve-osmancik-romanlarinda-tasvir-edilen-osman-bey-inpsikolojik-portresi

2- http://www.ekitaparsivi.com/kd.asp?id=2336\&/ekitaparsivi/Kemal\%20Tahir/devlet-ana_e-book_devlet-ana_e-kitap.html 